\title{
Allometric Scaling in the Dentition of Primates and Prediction of Body Weight From Tooth Size in Fossils
}

\author{
PHILIP D. GINGERICH, B. HOLLY SMITH, AND KAREN ROSENBERG \\ Museum of Paleontology (P.D.G.) and Department of Anthropology (B.H.S. \\ and K.R.), The University of Michigan, Ann Arbor, Michigan 48109
}

\author{
KEY WORDS Primate dentition, Allometry, Body size, Adapidae, \\ Hominoidea
}

\begin{abstract}
Tooth size varies exponentially with body weight in primates. Logarithmic transformation of tooth crown area and body weight yields a linear model of slope 0.67 as an isometric (geometric) baseline for study of dental allometry. This model is compared with that predicted by metabolic scaling (slope $=0.75$ ). Tarsius and other insectivores have larger teeth for their body size than generalized primates do, and they are not included in this analysis. Among generalized primates, tooth size is highly correlated with body size. Correlations of upper and lower cheek teeth with body size range from $0.90-0.97$, depending on tooth position. Central cheek teeth $\left(\mathbf{P}_{4}^{4}\right.$ and $\left.\mathbf{M}_{1}^{1}\right)$ have allometric coefficients ranging from 0.57-0.65, falling well below geometric scaling. Anterior and posterior cheek teeth scale at or above metabolic scaling. Considered individually or as a group, upper cheek teeth scale allometrically with lower coefficients than corresponding lower cheek teeth; the reverse is true for incisors. The sum of crown areas for all upper cheek teeth scales significantly below geometric scaling, while the sum of crown areas for all lower cheek teeth approximates geometric scaling. Tooth size can be used to predict the body weight of generalized fossil primates. This is illustrated for Aegyptopithecus and other Eocene, Oligocene, and Miocene primates. Regressions based on tooth size in generalized primates yield reasonable estimates of body weight, but much remains to be learned about tooth size and body size scaling in more restricted systematic groups and dietary guilds.
\end{abstract}

Body size is one of the most important parameters for understanding the life history and ecology of primates and other mammals (Western, 1979). Body size influences the relative abundance and systematic diversity of animals in structured faunas (Hutchinson and MacArthur, 1959; McNab, 1971; Van Valen, 1973), body architecture and function (Schmidt-Nielsen, 1975), locomotion and substrate preference (Fleagle and Mittermeier, 1980), sexual dimorphism and social organization (Clutton-Brock and Harvey, 1977; Clutton-Brock et al., 1977), home range size (Milton and May, 1976), neonatal weight (Leutenegger, 1976), and longevity (Sacher, 1959). Insectivorous, frugivorous, and folivorous living primates can be distinguished by the size, shape, and position of molar cusps and crests, and they also have characteristic body size distributions (Kay, 1975b, 1978; Kay and Hylander, 1978; Fleagle, 1978). Because most fossil primates are represented by dental remains, it is important to understand how tooth size is related to body size in order to reconstruct the life history and ecology of fossil species. In this paper we examine the relationship between tooth size and body size in generalized primates.

Tooth crown area (crown length multiplied by crown width) increases in relation to the square of a linear dimension, whereas body

Received June 10, 1981; accepted October 5, 1981. 
weight, being proportional to volume, increases in relation to the cube of a linear dimension, assuming geometric similarity is maintained. Thus one might predict theoretically that tooth area should increase or decrease as the $2 / 3$ (or 0.67 ) power of body weight. This is the "geometric scaling" model - the model that describes how area and volume are related if geometric similarity is maintained. Alternatively, one might expect tooth crown area, being directly involved in feeding and hence metabolism, to conform to metabolic scaling, which is proportional to the $3 / 4$ (or 0.75 ) power of body weight (Schmidt-Nielsen, 1975; Gould, 1975). This is the "metabolic scaling" model - the model that describes how area and volume are related if area scales in proportion to metabolism. Other alternatives are also possible (e.g., McMahon, 1973; Alexander et al., 1979), but these are the two most widely discussed in the literature on allometric scaling of tooth size.

In an absolute sense, large mammals usually have larger teeth than small mammals, but large mammals may have relatively larger teeth, relatively smaller teeth, or teeth of the same relative size as those of small mammals when differences in body size are taken into account. Both the geometric scaling model and the metabolic scaling model are illustrated in Figure 1, where the region between the two is stippled for clarity. Both models involve exponents less than unity (i.e. they are nonlinear). Thus in testing how well a given set of data points conforms to one or the other model, it is appropriate to fit an exponential equation of the form: $\mathrm{Y}=b \mathrm{X}^{a}$, where $\mathrm{X}$ is body size, $\mathrm{Y}$ is tooth size, $b$ is a constant, and $a$ is the exponent or allometric scaling coefficient (Huxley, 1932; Gould, 1966). Analytically, the easiest way to determine the parameters $a$ and $b$ is to transform both sides of this equation to logarithms: $\log \mathrm{Y}=\log b+a \log \mathrm{X}$, making it a linear equation of slope $a$ and Y-intercept $\log b$.

A number of authors have investigated the relationship of tooth size to body size in mammals using skull length, femur length, or headand-body length as a measure of body size (Pilbeam and Gould, 1974; Corruccini and Henderson, 1978; Pirie, 1978; Wood, 1979a, b; Wood and Stack, 1980; Creighton, 1980; see also Smith, 1981). Others have examined this problem by relating a specific measure of tooth size (incisor size, $\mathrm{M}_{2}$ length and/or width, or postcanine cheek tooth area) to body weight (Pilbeam and Gould, 1974; Gould, 1975; Hylander, 1975; Kay 1975a, b, 1978; Gingerich, 1976, 1977a; Goldstein et al., 1978). In this paper we analyze tooth size at all positions individually to see how tooth size scales in relation to body weight. We also analyze the summed area of the postcanine cheek teeth in relation to body weight for both the upper and lower dentition.

We use body weight (mass) as our measure of body size because, among the measures most commonly used, this quantity facilitates comparison among animals of different head-andbody shape. Other authors have defended cranial length, femur length, or head-and-body length because these can more often be measured directly on the same individual specimens as the teeth under study and because they generally exhibit less intraspecific variation than body weight (Yablokov, 1974). The latter observation is at least partially an artifact of comparison of quantities of different dimensionality (Lande, 1977). Measuring tooth size and body size on the same individuals is essential in studying the intraspecific relationship of these quantities, but we are interested here in interspecific patterns of scaling across the order Primates. The total range of body sizes involved in this study is so much greater than within-species variability that we feel justified in combining average tooth size measurements for a species with body weights taken from a different source. We emphasize that this study is concerned with interspecific allometric scaling across an order and not intraspecific scaling within individual species.

\section{MATERIALS AND METHODS}

The most extensive compilation of information on tooth size in primates is the recent book by Swindler (1976). Swindler lists means and standard deviations of tooth length and width for (in most cases) large samples of both males and females of 56 species of primates. Initially we used all of the species in Swindler's book for which body weights were also available. A preliminary analysis indicated that Tarsius and tree shrews do not fall on the same regressions as more typical primates (Fig. 2B). They have relatively larger cheek teeth than would be predicted for generalized primates of their body size. This is probably a consequence of their specialized insectivorous dietary adaptation. Primates used in the analysis presented here include species representing the superfamilies Lemuroidea (3 species), Lorisoidea (4 species), Ceboidea (8 species), Cercopithecoidea (21 species), and Hominoidea (7 species). Tarsius and tree shrews were not included. Measure- 


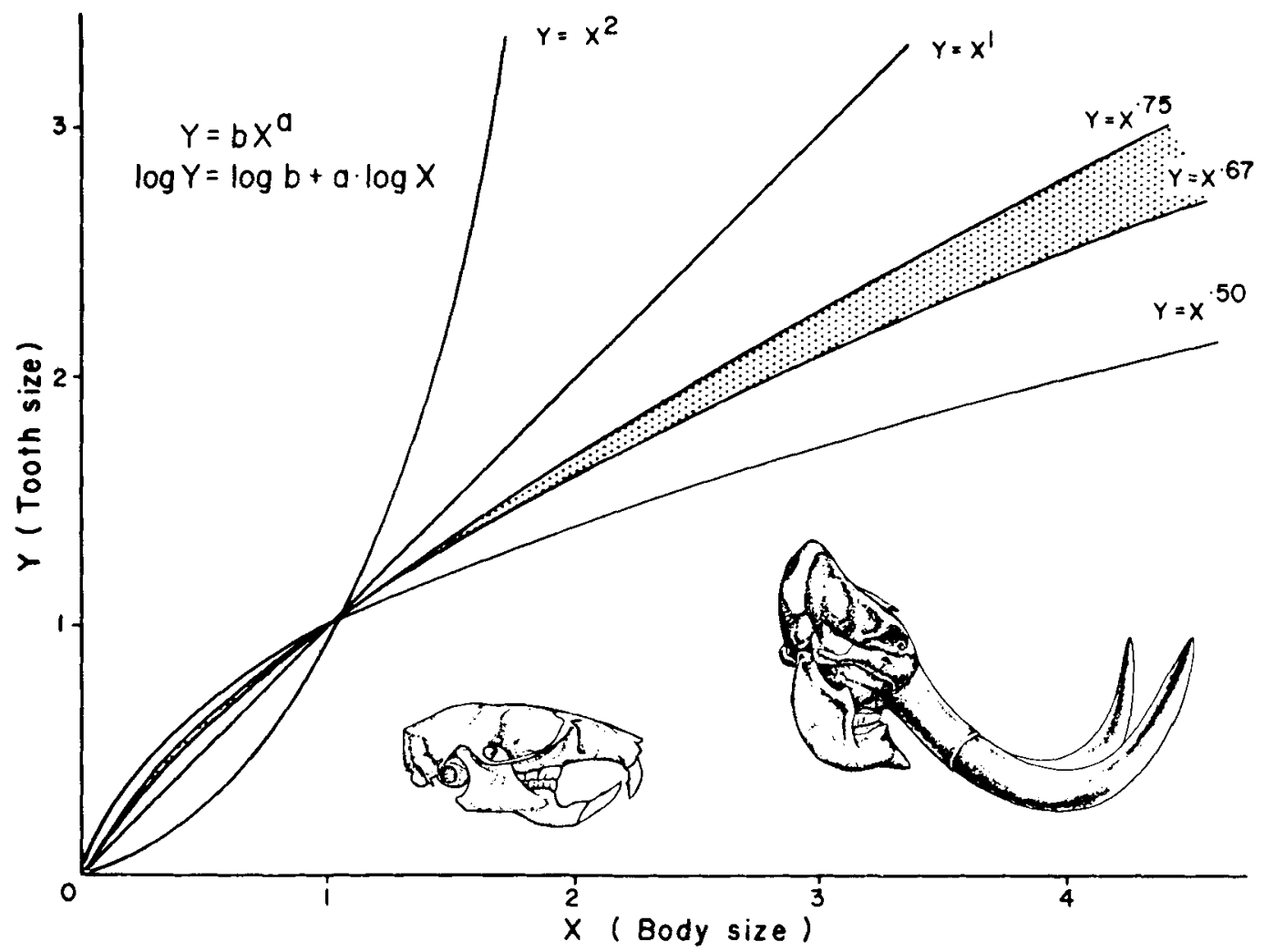

Fig. 1. Exponential models showing allometric change in tooth size $(\mathrm{Y})$ as a function of body size (X), where exponent $a$ is the allometric coefficient and $b$ is a constant. $Y=X^{\prime}$ is an isometric baseline for comparison of measures of tooth size and body size where both have the same dimensionality (i.e. both are lengths, both are areas, or both are volumes). $\mathrm{Y}=\mathrm{X}{ }^{.67}$ is the isometric baseline for comparison of tooth crown area with body weight or volume (the "geometric model") in this paper. $Y=$ $\mathrm{X}^{.75}$ represents metabolic scaling of tooth crown area and body weight. Logarithmic transformation, or conversion of linear scales shown here to logarithmic scales, makes each curve linear of slope $a(1.00,0.67$, or 0.75 in the examples discussed here). Inset figures show that cheek tooth length in an elephant is equal to or less than that in a mouse when both are brought to the same skull length. This implies allometric scaling of tooth size equal to or less than isometric (geometric) scaling.

ments of lower incisors and canines are not included for those species having a specialized anterior tooth comb.

We used tooth crown area (mesial-distal crown length multiplied by buccal-lingual width, or $L \times W /$ as our measure of tooth size. This compound measure has several advantages over the use of length or width alone. Crown area is based on two independent (orthogonal) measures of the same tooth, yield. ing a more accurate measure of tooth size than that given by any single measurement. Differences in crown shape have less influence on crown area than they do on individual length and width measurements. Kay (1975b) stated that frugivorous noncercopithecoid primates have small teeth for their adult body size. However, analysis of tooth crown area for the same frugivorous and folivorous noncercopithecoid species in our study indicates only a slight tendency in this direction. We attribute Kay's result, in part, to the fact that he used the length of $\mathrm{M}_{2}$ as a measure of tooth size, whereas we considered both length and width. Frugivorous species have short, broad lower molars and folivorous species have long, narrow lower molars: there is a shape difference but apparently little or no difference in crown area. Cercopithecoid frugivores and folivores cannot be differentiated by either relative tooth length (Kay and Hylander, 1978) or crown area (this study). 
TABLE 1. Species included in this study, including sex, sample size for tooth measurements, measurements of upper and lower first molars, and body weights.

\begin{tabular}{|c|c|c|c|c|c|c|c|}
\hline \multirow[b]{2}{*}{ Genus and species } & \multirow[b]{2}{*}{ Sex } & \multirow[b]{2}{*}{$(\mathrm{N})$} & \multicolumn{2}{|c|}{$\mathbf{M}^{1}$} & \multicolumn{2}{|c|}{$\mathbf{M}_{1}$} & \multirow[b]{2}{*}{$\begin{array}{c}\text { Body weight } \\
\text { (gm) }\end{array}$} \\
\hline & & & $\begin{array}{c}\mathrm{L} \\
(\mathrm{mm})\end{array}$ & $\begin{array}{c}\mathbf{W} \\
(\mathrm{mm})\end{array}$ & $\begin{array}{c}\mathrm{L} \\
(\mathrm{mm})\end{array}$ & $\begin{array}{c}W \\
(\mathrm{~mm})\end{array}$ & \\
\hline Lepilemur mustelinus & $\begin{array}{l}\mathrm{M} \\
\mathrm{F}\end{array}$ & $\begin{array}{l}(6) \\
(11)\end{array}$ & $\begin{array}{l}3.50 \\
3.40\end{array}$ & $\begin{array}{l}3.27 \\
3.46\end{array}$ & $\begin{array}{l}3.50 \\
3.56\end{array}$ & $\begin{array}{l}2.25 \\
2.36\end{array}$ & $\begin{array}{l}610 \\
640\end{array}$ \\
\hline Varecia variegata & $\begin{array}{l}\mathrm{M} \\
\mathrm{F}\end{array}$ & $\begin{array}{c}(6) \\
(-1)\end{array}$ & $\begin{array}{c}7.30 \\
-\end{array}$ & $\begin{array}{l}7.60 \\
-\end{array}$ & $\begin{array}{c}7.80 \\
-\end{array}$ & $\begin{array}{c}4.60 \\
-\end{array}$ & 3,086 \\
\hline Propithecus verreauxi & $\begin{array}{l}\mathrm{M} \\
\mathrm{F}\end{array}$ & $\begin{array}{l}(22) \\
(24)\end{array}$ & $\begin{array}{l}6.85 \\
6.94\end{array}$ & $\begin{array}{l}6.25 \\
6.30\end{array}$ & $\begin{array}{l}6.68 \\
6.65\end{array}$ & $\begin{array}{l}4.57 \\
4.54\end{array}$ & $\begin{array}{l}3,700 \\
3,500\end{array}$ \\
\hline Nycticebus coucang & $\begin{array}{l}\mathrm{M} \\
\mathrm{F}\end{array}$ & $\begin{array}{l}(21) \\
(9)\end{array}$ & $\begin{array}{l}3.50 \\
3.50\end{array}$ & $\begin{array}{l}4.30 \\
4.20\end{array}$ & $\begin{array}{l}3.40 \\
3.40\end{array}$ & $\begin{array}{l}2.70 \\
2.70\end{array}$ & $\begin{array}{l}1,300 \\
1,200\end{array}$ \\
\hline Perodicticus potto & $\begin{array}{l}\mathrm{M} \\
\mathrm{F}\end{array}$ & $\begin{array}{l}(12) \\
(10)\end{array}$ & $\begin{array}{l}3.50 \\
3.40\end{array}$ & $\begin{array}{l}4.00 \\
3.80\end{array}$ & $\begin{array}{l}3.20 \\
3.10\end{array}$ & $\begin{array}{l}2.70 \\
2.50\end{array}$ & $\begin{array}{l}1,200 \\
1,100\end{array}$ \\
\hline Galago crassicaudatus & $\begin{array}{l}\mathrm{M} \\
\mathrm{F}\end{array}$ & $\begin{array}{l}(20) \\
(11)\end{array}$ & $\begin{array}{l}4.20 \\
4.40\end{array}$ & $\begin{array}{l}5.00 \\
4.90\end{array}$ & $\begin{array}{l}3.90 \\
4.00\end{array}$ & $\begin{array}{l}3.30 \\
3.20\end{array}$ & $\begin{array}{l}1,200 \\
1,000\end{array}$ \\
\hline Galago senegalensis & $\begin{array}{l}\mathbf{M} \\
\mathbf{F}\end{array}$ & $\begin{array}{l}(24) \\
(20)\end{array}$ & $\begin{array}{l}2.50 \\
2.50\end{array}$ & $\begin{array}{l}3.00 \\
3.00\end{array}$ & $\begin{array}{l}2.30 \\
2.20\end{array}$ & $\begin{array}{l}1.90 \\
1.90\end{array}$ & $\begin{array}{l}300 \\
300\end{array}$ \\
\hline Saguinus geoffroyi & $\begin{array}{l}\mathbf{M} \\
\mathbf{F}\end{array}$ & $\begin{array}{l}(11) \\
(15)\end{array}$ & $\begin{array}{l}2.80 \\
2.90\end{array}$ & $\begin{array}{l}3.60 \\
3.90\end{array}$ & $\begin{array}{l}2.80 \\
2.90\end{array}$ & $\begin{array}{l}2.30 \\
2.30\end{array}$ & $\begin{array}{l}500 \\
510\end{array}$ \\
\hline Aotus trivirgatus & $\begin{array}{l}\mathbf{M} \\
\mathbf{F}\end{array}$ & $\begin{array}{l}(9) \\
(15)\end{array}$ & $\begin{array}{l}3.30 \\
3.30\end{array}$ & $\begin{array}{l}4.10 \\
3.90\end{array}$ & $\begin{array}{l}3.30 \\
3.30\end{array}$ & $\begin{array}{l}2.90 \\
2.90\end{array}$ & $\begin{array}{r}920 \\
1,000\end{array}$ \\
\hline Ateles geoffroyi & $\begin{array}{l}\mathbf{M} \\
\mathbf{F}\end{array}$ & $\begin{array}{l}(14) \\
(15)\end{array}$ & $\begin{array}{l}4.90 \\
5.30\end{array}$ & $\begin{array}{l}5.50 \\
5.70\end{array}$ & $\begin{array}{l}5.20 \\
5.30\end{array}$ & $\begin{array}{l}5.00 \\
5.10\end{array}$ & $\begin{array}{l}6,200 \\
5,800\end{array}$ \\
\hline Cebus apella & $\begin{array}{l}\mathbf{M} \\
\mathbf{F}\end{array}$ & $\begin{array}{l}(35) \\
(21)\end{array}$ & $\begin{array}{l}4.69 \\
4.56\end{array}$ & $\begin{array}{l}6.31 \\
6.04\end{array}$ & $\begin{array}{l}5.03 \\
4.86\end{array}$ & $\begin{array}{l}5.09 \\
4.80\end{array}$ & $\begin{array}{l}1,947 \\
1,521\end{array}$ \\
\hline Saimiri oerstedii & $\begin{array}{l}\mathbf{M} \\
\mathbf{F}\end{array}$ & $\begin{array}{l}(11) \\
(6)\end{array}$ & $\begin{array}{l}2.80 \\
2.70\end{array}$ & $\begin{array}{l}3.90 \\
3.70\end{array}$ & $\begin{array}{l}3.00 \\
2.70\end{array}$ & $\begin{array}{l}2.80 \\
2.60\end{array}$ & $\begin{array}{l}904 \\
637\end{array}$ \\
\hline Saimiri sciureus & $\begin{array}{l}\mathbf{M} \\
\mathbf{F}\end{array}$ & $\begin{array}{l}(21) \\
(6)\end{array}$ & $\begin{array}{l}2.80 \\
2.80\end{array}$ & $\begin{array}{l}4.10 \\
4.00\end{array}$ & $\begin{array}{l}2.90 \\
2.90\end{array}$ & $\begin{array}{l}2.80 \\
2.80\end{array}$ & $\begin{array}{l}750 \\
580\end{array}$ \\
\hline Alouatta seniculus & $\begin{array}{l}\mathbf{M} \\
\mathbf{F}\end{array}$ & $\begin{array}{l}(20) \\
(20)\end{array}$ & $\begin{array}{l}7.47 \\
7.10\end{array}$ & $\begin{array}{l}7.99 \\
7.30\end{array}$ & $\begin{array}{l}7.58 \\
7.20\end{array}$ & $\begin{array}{l}5.38 \\
5.10\end{array}$ & $\begin{array}{l}8,100 \\
6,400\end{array}$ \\
\hline Alouatta villosa & $\begin{array}{l}\mathrm{M} \\
\mathrm{F}\end{array}$ & $\begin{array}{l}(15) \\
(37)\end{array}$ & $\begin{array}{l}7.10 \\
6.90\end{array}$ & $\begin{array}{l}8.10 \\
7.30\end{array}$ & $\begin{array}{l}7.10 \\
6.80\end{array}$ & $\begin{array}{l}5.50 \\
5.20\end{array}$ & $\begin{array}{l}7,400 \\
5,700\end{array}$ \\
\hline Cercopithecus cephus & $\begin{array}{l}\mathrm{M} \\
\mathrm{F}\end{array}$ & $\begin{array}{l}\text { (9) } \\
(12)\end{array}$ & $\begin{array}{l}5.70 \\
5.40\end{array}$ & $\begin{array}{l}5.30 \\
5.10\end{array}$ & $\begin{array}{l}5.60 \\
5.40\end{array}$ & $\begin{array}{l}4.10 \\
3.80\end{array}$ & $\begin{array}{l}4,100 \\
2,900\end{array}$ \\
\hline Cercopithecus nictitans & $\begin{array}{l}\mathbf{M} \\
\mathbf{F}\end{array}$ & $\begin{array}{l}(11) \\
(7)\end{array}$ & $\begin{array}{l}5.60 \\
5.50\end{array}$ & $\begin{array}{l}5.10 \\
5.10\end{array}$ & $\begin{array}{l}5.70 \\
5.50\end{array}$ & $\begin{array}{l}4.00 \\
3.90\end{array}$ & $\begin{array}{l}6,600 \\
4,200\end{array}$ \\
\hline Cercopithecus mona & $\begin{array}{l}\mathrm{M} \\
\mathrm{F}\end{array}$ & $\begin{array}{l}(27) \\
(16)\end{array}$ & $\begin{array}{l}5.30 \\
5.30\end{array}$ & $\begin{array}{l}5.20 \\
5.00\end{array}$ & $\begin{array}{l}5.30 \\
5.20\end{array}$ & $\begin{array}{l}3.90 \\
3.70\end{array}$ & $\begin{array}{l}4,768 \\
3,700\end{array}$ \\
\hline Cercopithecus mitis & $\begin{array}{l}\mathrm{M} \\
\mathrm{F}\end{array}$ & $\begin{array}{l}(31) \\
(21)\end{array}$ & $\begin{array}{l}6.10 \\
5.90\end{array}$ & $\begin{array}{l}5.50 \\
5.40\end{array}$ & $\begin{array}{l}6.20 \\
6.00\end{array}$ & $\begin{array}{l}4.30 \\
4.30\end{array}$ & $\begin{array}{l}7,400 \\
5,300\end{array}$ \\
\hline Cercopithecus neglectus & $\begin{array}{l}\mathrm{M} \\
\mathrm{F}\end{array}$ & $\begin{array}{r}(13) \\
(7)\end{array}$ & $\begin{array}{l}6.30 \\
5.90\end{array}$ & $\begin{array}{l}5.50 \\
5.20\end{array}$ & $\begin{array}{l}6.30 \\
5.90\end{array}$ & $\begin{array}{l}4.40 \\
4.40\end{array}$ & $\begin{array}{l}7,000 \\
4,000\end{array}$ \\
\hline Cercopithecus ascanius & $\begin{array}{l}\mathrm{M} \\
\mathrm{F}\end{array}$ & $\begin{array}{l}(19) \\
(13)\end{array}$ & $\begin{array}{l}5.09 \\
4.91\end{array}$ & $\begin{array}{l}4.78 \\
4.76\end{array}$ & $\begin{array}{l}5.20 \\
5.01\end{array}$ & $\begin{array}{l}3.79 \\
3.62\end{array}$ & $\begin{array}{l}4,200 \\
2,900\end{array}$ \\
\hline Cercopithecus aethiops & $\begin{array}{l}\mathrm{M} \\
\mathrm{F}\end{array}$ & $\begin{array}{l}(29) \\
(20)\end{array}$ & $\begin{array}{l}5.74 \\
5.36\end{array}$ & $\begin{array}{l}5.59 \\
5.23\end{array}$ & $\begin{array}{l}5.88 \\
5.59\end{array}$ & $\begin{array}{l}4.40 \\
4.18\end{array}$ & $\begin{array}{l}5,000 \\
3,750\end{array}$ \\
\hline Cercocebus albigena & $\begin{array}{l}\mathrm{M} \\
\mathrm{F}\end{array}$ & $\begin{array}{l}(31) \\
(29)\end{array}$ & $\begin{array}{l}7.00 \\
6.56\end{array}$ & $\begin{array}{l}6.73 \\
6.22\end{array}$ & $\begin{array}{l}6.88 \\
6.49\end{array}$ & $\begin{array}{l}5.57 \\
5.18\end{array}$ & $\begin{array}{l}9,000 \\
6,400\end{array}$ \\
\hline Cercocebus torquatus & $\begin{array}{l}\text { M } \\
\text { F }\end{array}$ & $\begin{array}{l}(14) \\
(10)\end{array}$ & $\begin{array}{l}7.50 \\
7.20\end{array}$ & $\begin{array}{l}7.80 \\
7.60\end{array}$ & $\begin{array}{l}7.30 \\
7.30\end{array}$ & $\begin{array}{l}6.10 \\
6.00\end{array}$ & $\begin{array}{l}8,000 \\
5,500\end{array}$ \\
\hline Cercocebus galeritus & $\begin{array}{l}\mathbf{M} \\
\mathbf{F}\end{array}$ & $\begin{array}{l}(10) \\
(10)\end{array}$ & $\begin{array}{l}7.30 \\
7.10\end{array}$ & $\begin{array}{l}8.10 \\
7.40\end{array}$ & $\begin{array}{l}7.40 \\
7.00\end{array}$ & $\begin{array}{l}6.40 \\
5.90\end{array}$ & $\begin{array}{r}10,200 \\
5,500\end{array}$ \\
\hline Macaca nemestrina & $\begin{array}{c}\mathbf{M} \\
\mathbf{F}\end{array}$ & $\begin{array}{l}(19) \\
(11)\end{array}$ & $\begin{array}{l}7.40 \\
7.10\end{array}$ & $\begin{array}{l}7.20 \\
7.10\end{array}$ & $\begin{array}{l}7.50 \\
7.30\end{array}$ & $\begin{array}{l}5.80 \\
5.60\end{array}$ & $\begin{array}{r}10,400 \\
7,800\end{array}$ \\
\hline Macaca mulatta & $\begin{array}{l}\mathrm{M} \\
\mathrm{F}\end{array}$ & $\begin{array}{c}(103) \\
(87)\end{array}$ & $\begin{array}{l}7.20 \\
7.10\end{array}$ & $\begin{array}{l}7.00 \\
6.80\end{array}$ & $\begin{array}{l}7.20 \\
7.00\end{array}$ & $\begin{array}{l}5.60 \\
5.50\end{array}$ & $\begin{array}{l}8,200 \\
7,500\end{array}$ \\
\hline Macaca fascicularis & $\begin{array}{l}\mathbf{M} \\
\mathbf{F}\end{array}$ & $\begin{array}{l}(66) \\
(56)\end{array}$ & $\begin{array}{l}6.50 \\
6.30\end{array}$ & $\begin{array}{l}6.40 \\
6.20\end{array}$ & $\begin{array}{l}6.50 \\
6.40\end{array}$ & $\begin{array}{l}5.10 \\
5.10\end{array}$ & $\begin{array}{l}5,900 \\
4,100\end{array}$ \\
\hline Macaca speciosa & $\begin{array}{l}\mathbf{M} \\
\mathbf{F}\end{array}$ & $\begin{array}{c}(7) \\
(-)\end{array}$ & $\begin{array}{l}8.40 \\
-\end{array}$ & $\begin{array}{c}8.50 \\
-\end{array}$ & $\begin{array}{l}8.40 \\
-\end{array}$ & $\begin{array}{c}6.30 \\
-\end{array}$ & $\begin{array}{c}10,473 \\
-\end{array}$ \\
\hline
\end{tabular}


TABLE 1. Species included in this study, including sex, sample size for tooth measurements, measurements of upper and lower first molars, and body weights (continued)

\begin{tabular}{|c|c|c|c|c|c|c|c|}
\hline \multirow[b]{2}{*}{ Genus and species } & \multirow[b]{2}{*}{ Sex } & \multirow[b]{2}{*}{$(\mathrm{N})$} & \multicolumn{2}{|c|}{$\mathbf{M}^{1}$} & \multicolumn{2}{|c|}{$\mathrm{M}_{\mathbf{r}}$} & \multirow[b]{2}{*}{$\begin{array}{l}\text { Body weight } \\
\text { (gm) }\end{array}$} \\
\hline & & & $\begin{array}{c}\mathrm{L} \\
(\mathrm{mm})\end{array}$ & $\begin{array}{c}W \\
(\mathrm{~mm})\end{array}$ & $\begin{array}{c}\mathrm{L} \\
(\mathrm{mm})\end{array}$ & $\begin{array}{c}W \\
(\mathrm{~mm})\end{array}$ & \\
\hline Cynopithecus niger & $\begin{array}{l}\mathrm{M} \\
\mathrm{F}\end{array}$ & $\begin{array}{l}(10) \\
(7)\end{array}$ & $\begin{array}{l}7.10 \\
6.40\end{array}$ & $\begin{array}{l}6.50 \\
6.00\end{array}$ & $\begin{array}{l}7.10 \\
6.60\end{array}$ & $\begin{array}{l}5.20 \\
4.90\end{array}$ & $\begin{array}{r}10,400 \\
6,600\end{array}$ \\
\hline Theropithecus gelada & $\begin{array}{l}\mathrm{M} \\
\mathrm{F}\end{array}$ & $\begin{array}{l}(37) \\
(24)\end{array}$ & 10.70 & $\begin{array}{l}9.30 \\
8.70\end{array}$ & - & $\begin{array}{l}7.50 \\
7.20\end{array}$ & $\begin{array}{l}20,500 \\
13,600\end{array}$ \\
\hline Colobus polykomos & $\begin{array}{l}M \\
F\end{array}$ & $\begin{array}{l}(49) \\
(31)\end{array}$ & $\begin{array}{l}7.00 \\
6.80\end{array}$ & $\begin{array}{l}6.50 \\
6.20\end{array}$ & $\begin{array}{l}7.20 \\
7.00\end{array}$ & $\begin{array}{l}5.50 \\
5.20\end{array}$ & $\begin{array}{r}10,400 \\
8,400\end{array}$ \\
\hline Colobus badius & $\begin{array}{l}\mathrm{M} \\
\mathrm{F}\end{array}$ & $\begin{array}{l}(26) \\
(27)\end{array}$ & $\begin{array}{l}7.00 \\
6.90\end{array}$ & $\begin{array}{l}6.00 \\
6.00\end{array}$ & $\begin{array}{l}7.20 \\
7.10\end{array}$ & $\begin{array}{l}5.00 \\
5.00\end{array}$ & $\begin{array}{r}10,500 \\
5,800\end{array}$ \\
\hline Nasalis larvatus & $\begin{array}{l}\text { M } \\
\text { F }\end{array}$ & $\begin{array}{l}(21) \\
(14)\end{array}$ & $\begin{array}{l}7.00 \\
6.80\end{array}$ & $\begin{array}{l}6.30 \\
6.00\end{array}$ & $\begin{array}{l}7.30 \\
6.90\end{array}$ & $\begin{array}{l}5.30 \\
5.00\end{array}$ & $\begin{array}{l}17,700 \\
10,000\end{array}$ \\
\hline Presbytis aygula & $\begin{array}{l}\mathrm{M} \\
\mathrm{F}\end{array}$ & $\begin{array}{l}(20) \\
(26)\end{array}$ & $\begin{array}{l}5.30 \\
5.30\end{array}$ & $\begin{array}{l}5.60 \\
5.30\end{array}$ & $\begin{array}{l}5.50 \\
5.40\end{array}$ & $\begin{array}{l}4.50 \\
4.30\end{array}$ & $\begin{array}{l}6,300 \\
6,200\end{array}$ \\
\hline Presbytis cristatus & $\begin{array}{l}\mathbf{M} \\
\mathbf{F}\end{array}$ & $\begin{array}{l}(22) \\
(33)\end{array}$ & $\begin{array}{l}5.95 \\
5.79\end{array}$ & $\begin{array}{l}5.88 \\
5.84\end{array}$ & $\begin{array}{l}6.12 \\
5.98\end{array}$ & $\begin{array}{l}4.74 \\
4.71\end{array}$ & $\begin{array}{l}8,600 \\
8,100\end{array}$ \\
\hline Hylobates klossii & $\begin{array}{l}\mathbf{M} \\
\mathbf{F}\end{array}$ & $\begin{array}{l}(5) \\
(4)\end{array}$ & $\begin{array}{l}5.50 \\
5.20\end{array}$ & $\begin{array}{l}5.90 \\
5.70\end{array}$ & $\begin{array}{l}6.00 \\
5.80\end{array}$ & $\begin{array}{l}4.70 \\
4.60\end{array}$ & $\begin{array}{l}5,900 \\
5,700\end{array}$ \\
\hline Hylobates agilis & $\underset{F}{M}$ & $\begin{array}{l}(8) \\
(9)\end{array}$ & $\begin{array}{l}5.70 \\
5.60\end{array}$ & $\begin{array}{l}6.00 \\
6.00\end{array}$ & $\begin{array}{l}6.00 \\
6.00\end{array}$ & $\begin{array}{l}4.90 \\
4.90\end{array}$ & $\begin{array}{l}6,000 \\
5,700\end{array}$ \\
\hline Hylobates moloch & $\begin{array}{l}\mathbf{M} \\
\mathrm{F}\end{array}$ & $\left(\begin{array}{l}5 \\
(5)\end{array}\right.$ & $\begin{array}{l}5.90 \\
5.70\end{array}$ & $\begin{array}{l}6.50 \\
6.30\end{array}$ & $\begin{array}{l}6.40 \\
6.20\end{array}$ & $\begin{array}{l}5.20 \\
4.90\end{array}$ & $\begin{array}{l}6,000 \\
5,700\end{array}$ \\
\hline Hylobates lar & $\begin{array}{l}\mathrm{M} \\
\mathrm{F}\end{array}$ & $\begin{array}{c}(5) \\
(-1\end{array}$ & $\begin{array}{c}5.40 \\
-\end{array}$ & $\begin{array}{c}5.50 \\
-\end{array}$ & $\begin{array}{c}5.60 \\
-\end{array}$ & $\begin{array}{c}4.40 \\
-\end{array}$ & $\begin{array}{c}4.785 \\
-\end{array}$ \\
\hline Pongo pygmaeus & $\mathrm{M}$ & $\begin{array}{l}(8) \\
(10)\end{array}$ & $\begin{array}{l}12.80 \\
11.90\end{array}$ & $\begin{array}{l}13.80 \\
12.20\end{array}$ & $\begin{array}{l}13.40 \\
11.40\end{array}$ & $\begin{array}{l}11.90 \\
11.10\end{array}$ & $\begin{array}{l}69,000 \\
37,000\end{array}$ \\
\hline Pan troglodytes & $\begin{array}{l}\mathrm{M} \\
\mathrm{F}\end{array}$ & $\begin{array}{l}(19) \\
(51)\end{array}$ & $\begin{array}{l}10.30 \\
10.10\end{array}$ & $\begin{array}{l}11.70 \\
10.90\end{array}$ & $\begin{array}{l}11.00 \\
10.80\end{array}$ & $\begin{array}{r}10.00 \\
9.40\end{array}$ & $\begin{array}{l}43,900 \\
31,500\end{array}$ \\
\hline Gorilla gorilla & $\begin{array}{l}\mathrm{M} \\
\mathrm{F} \\
\end{array}$ & $\begin{array}{r}(6) \\
(11) \\
\end{array}$ & $\begin{array}{l}15.70 \\
14.80 \\
\end{array}$ & $\begin{array}{l}15.40 \\
15.00 \\
\end{array}$ & $\begin{array}{l}16.20 \\
15.40 \\
\end{array}$ & $\begin{array}{l}13.70 \\
13.20 \\
\end{array}$ & $\begin{array}{r}160,000 \\
93,000 \\
\end{array}$ \\
\hline
\end{tabular}

Tooth measurements used in this study are taken from Swindler (1976) or Gingerich and Ryan (1979). Body weights are from Harvey et al (1978 or Bauchot and Stephan $\{1966,1969\}$.

Body weights were taken from Harvey et al. (1978) or Bauchot and Stephan (1966, 1969), compiled from various original sources. Body weights and other information used in our analyses are listed in Table 1 , which includes length and width measurements of upper and lower first molars $\left(\mathrm{M}_{1}^{1}\right)$ as examples. The remaining tooth measurements used in our analyses can be found in Swindler (1976) or Gingerich and Ryan (1979).

There are several methods of fitting a linear equation to a given logarithmically transformed scatter of points. We have used a principal or major axis fit (Sokal and Rohlf, 1969; Jolicoeur, 1973) to estimate the structural relationship between tooth size and body size. This is the basis for the allometric coefficients or slopes discussed in the first part of the paper. Confidence intervals for allo- metric coefficients, ranging from $k_{1}$ to $k_{2}$, were calculated following Jolicoeur (1973), where:

$$
\begin{aligned}
& k_{1}=\frac{\left(S_{22}-S_{12}\right)+\sqrt{\left(S_{22}-\overline{S_{11}}\right)^{2}+4 S_{12}^{2}-4 \bar{Q}}}{2 S_{12}+2 \sqrt{Q}} \\
& k_{2}=\frac{\left(S_{21}-S_{11}\right)-\sqrt{\left(S_{22}-\right.} \overline{\left.S_{11}\right)^{2}+4 S_{12}^{2}-4 Q}}{2 S_{12}+2 \sqrt{Q}}
\end{aligned}
$$

and

$Q=\frac{\left.F_{(1-a}+1, N-{ }_{2}\right)\left(S_{11} S_{12}-S_{12}^{2}\right)}{N-2}$

$S_{11}, S_{22}$, and $S_{12}$ are elements of the sample covariance matrix,

$$
\begin{aligned}
& S_{11}=V(Y) \quad[Y=\ln \text { tooth area }] \\
& S_{22}=V(X) \quad[X=\ln \text { body weight }] \\
& S_{12}=\text { correlation }(Y, X)\left(\sqrt{S_{11} S_{22}}\right)
\end{aligned}
$$

and $\mathrm{N}$ is the sample size. 
This method provides an actual confidence level of $(1-\alpha)$ if the sample size is not small ( $N$ $>10,20$ ) and correlation of the two variates $X$ and $Y$ is at least moderate $(\varrho>0.6)$. Both of these minimal conditions are met or exceeded in this study. We used a linear regression of body size on tooth size to derive equations estimating an unknown body size when tooth size is known. This has application in estimating body size in extinct primates and is discussed in the second part of the paper. In both cases, the correlation coefficient $r$ is a measure of how well the scatter of logarithmically transformed points approximates a straight line. Natural logarithms to base $e$ have been used throughout this paper.

\section{STRUCTURAL RELATIONSHIP OF TOOTH SIZE AND BODY SIZE IN PRIMATES}

R.J. Smith (1980) has questioned the appropriateness of fractional polynomial models (power functions) for studying the structural size relationship of various parts of organisms, but we feel that this can be justified (at least in the present study) on both theoretical and empirical grounds. In the introduction we showed how, theoretically, one might expect tooth crown area to increase as the square of a linear dimension while body weight increases in proportion to the cube of this linear dimension. Given geometric similarity, if tooth size $Y$ is proportional to $l^{2}$, and body size $X$ is proportional to $l^{3}$, then $Y$ is proportional to $X$ raised to the $2 / 3$ power. In other words, this "null hypothesis" of geometric similarity of tooth area and body weight is inherently a fractional polynomial (technically a monomial). McMahon (1973) gives a similar theoretical justification for the use of power functions in studying metabolic scaling.

Figure 2A illustrates graphically that a power function fits the scatter of untransformed body weights and tooth measurements in primates better than a straight line does. We can compare the goodness of fit of the linear and power function models by comparing the correlation coefficient of untransformed data (linear model, Fig. 2A) with that for logarithmically transformed measurements (Fig. 2B). The untransformed correlation coefficient is 0.937 , while that for transformed measurements is 0.967 . The latter is significantly greater than the former $(p<.02)$, which further justifies using both logarithmically transformed data and power functions in analyzing the relationship of tooth size to body size in primates.

\section{SCALING OF TOOTH SIZE AND BODY SIZE}

The distribution of points in Figure 2B shows graphically how lower first molar size (L $\times W$ of $\left.M_{1}\right)$ and body weight are correlated $(r=$ 0.967 ) in generalized primates. The slope of the principal axis of this distribution is 0.638 (or $0.64)$, which is less than geometric scaling $(0.67)$ but the difference between the two is not statistically significant. The difference between 0.64 and 0.75 is statistically significant $(p<.05)$. Taken together, these results indicate that the first lower molar in primates conforms to the geometric model of allometric scaling outlined above, and not to the metabolic model.

We have calculated the correlation $(r)$ and scaling coefficient (slope $a$ ) of tooth area and body weight at each tooth position in generalized primates. In addition, we have calculated the correlation and scaling of the sum of all upper and lower postcanine tooth areas with body weight. The results are listed in Table 2 along with the $95 \%$ confidence interval for each scaling coefficient. It should be noted that upper canines, upper molars, and lower cheek teeth (except $\mathrm{P}_{2}$ ) all have correlation coefficients of about 0.95 or greater. Lower central cheek teeth $\left(\mathrm{P}_{3}-\mathrm{M}_{2}\right)$ are more highly correlated with body size than are upper cheek teeth. As a result, these teeth are probably the best teeth to use to predict the body weight of a primate from its tooth size (see below). Many of the species used in this analysis are sexually dimorphic and upper canine size is usually proportional to the degree of dimorphism, which probably accounts for the high correlation of canine size with body size in this analysis.

Figure 3 shows the pattern of change in allometric scaling coefficients (slopes) along the tooth row in both the upper and lower dentition. In the upper dentition there is a smooth decline in scaling coefficients from $\mathrm{I}^{1}$ to $\mathrm{M}^{1}$, and then a steep increase from $M^{1}$ to $M^{3}$. The general pattern of scaling in the lower dentition is more complicated. Lower incisors have lower slopes than the lower canine and anterior premolars, then there is a decrease from $P_{3}$ to $M_{1}$ and, again, a steep increase from $M_{1}$ to $M_{3}$. The vertical bars associated with each point are the $95 \%$ confidence interval for the scaling coefficient at each tooth position. These show 

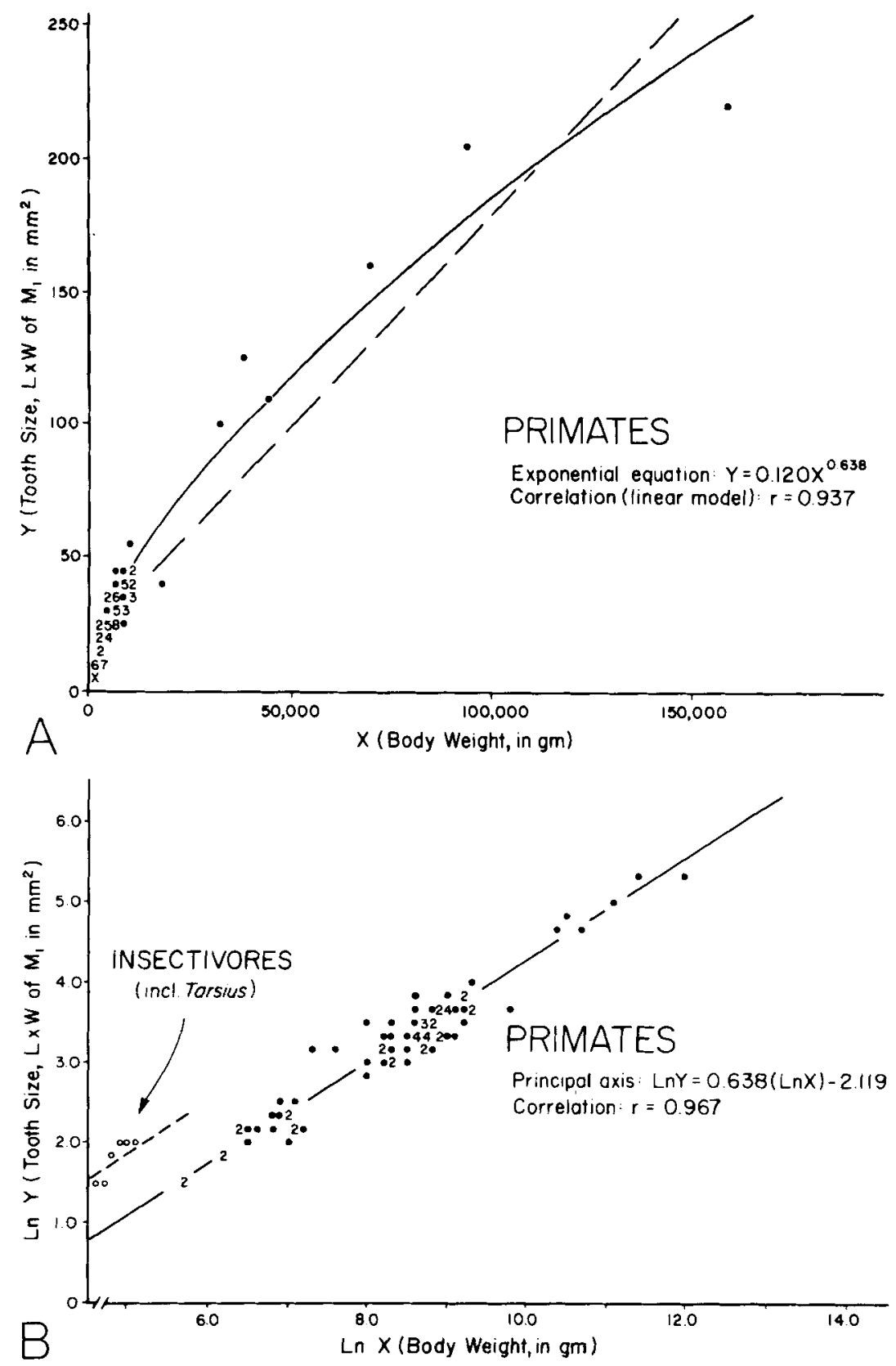

Fig. 2. Allometric scaling of tooth size and body size in primates. (A) Scatter plot of crown area of $\mathrm{M}_{1}$ against body weight, showing both linear (dashed line) and exponential curves fit to the data (curves are principal axes of untransformed and $\log$ transformed data, respectively). (B) Scatter plot of natural logarithm of crown area of $M_{3}$ against natural logarithm of body weight, showing that tooth size in tree shrews and Tarsius (open circles) scales differently than that in generalized primates (solid circles). Note that the correlation of $\ln$ tooth size with $\ln$ body weight $(r=0.967)$ is significantly greater than the correlation of tooth size and body weight $(r=0.937)$ in generalized primates $(p<.02)$. An exponent of 0.638 indicates tooth size/body weight allometry below geometric scaling (which would be 0.667 ). Each point represents an average for males or females of 43 species of generalized primates. Small numerals represent multiple points. Raw data and literature sources are listed in Table 1. 
TABLE 2. Correlation and allometric scaling of tooth crown area and body weight in primates

\begin{tabular}{|c|c|c|c|c|c|c|}
\hline $\begin{array}{l}\text { Tooth } \\
\text { Position }\end{array}$ & $\begin{array}{c}\text { Correlation } \\
(r)\end{array}$ & $\begin{array}{c}\text { Slope } \\
(a)\end{array}$ & $\begin{array}{c}95 \% \\
\text { Confidence } \\
\text { interval } \\
\text { of slope } \\
\end{array}$ & $\mathrm{N}$ & $s_{11}$ & $s_{22}$ \\
\hline \multicolumn{7}{|c|}{ UPPER DENTITION } \\
\hline$I^{1}$ & 0.835 & 0.79 & $0.68-0.93$ & 73 & 0.82 & 1.20 \\
\hline $\mathrm{I}^{2}$ & 0.858 & 0.75 & $0.65-0.86$ & 73 & 0.73 & 1.20 \\
\hline $\mathrm{C}^{1}$ & 0.947 & 0.72 & $0.67-0.78$ & 82 & 0.82 & 1.52 \\
\hline $\mathrm{P}^{2}$ & 0.902 & 0.70 & $0.57-0.84$ & 27 & 0.51 & 0.99 \\
\hline $\mathrm{P}^{3}$ & 0.943 & 0.65 & $0.60-0.70$ & 83 & 0.66 & 1.50 \\
\hline P4 & 0.934 & 0.59 & $0.54-0.64$ & 83 & 0.55 & 1.50 \\
\hline $\mathbf{M}^{1}$ & 0.946 & 0.57 & $0.53-0.61$ & 82 & 0.51 & 1.49 \\
\hline $\mathrm{M}^{2}$ & 0.945 & 0.68 & $0.63-0.73$ & 83 & 0.71 & 1.50 \\
\hline$M^{3}$ & 0.947 & 0.78 & $0.72-0.84$ & 81 & 0.87 & 1.41 \\
\hline$\Sigma$ Cheek Teeth & 0.949 & 0.62 & $0.57-0.67$ & 78 & 0.58 & 1,44 \\
\hline \multicolumn{7}{|c|}{ LOWER DENTITION } \\
\hline$I_{1}$ & 0.854 & 0.72 & $0.62-0.83$ & 70 & 0.68 & 1.18 \\
\hline$I_{2}$ & 0.921 & 0.65 & $0.58-0.72$ & 70 & 0.53 & 1.18 \\
\hline $\mathrm{C}_{\mathrm{t}}$ & 0.882 & 0.79 & $0.69-0.89$ & 75 & 0.83 & 1.27 \\
\hline$P_{2}$ & 0.913 & 0.76 & $0.63-0.91$ & 27 & 0.59 & 0.99 \\
\hline$P_{3}$ & 0.954 & 0.78 & $0.72-0.83$ & 83 & 0.92 & 1.50 \\
\hline$P_{4}$ & 0.955 & 0.65 & $0.61-0.70$ & 83 & 0.66 & 1.50 \\
\hline $\mathbf{M}_{1}$ & 0.967 & 0.64 & $0.60-0.68$ & 83 & 0.63 & 1.50 \\
\hline $\mathrm{M}_{2}$ & 0.968 & 0.73 & $0.69-0.77$ & 83 & 0.81 & 1.50 \\
\hline $\mathrm{M}_{3}$ & 0.947 & 0.80 & $0.74-0.86$ & 81 & 0.92 & 1.41 \\
\hline$\Sigma$ Cheek Teeth & 0.964 & 0.69 & $0.65-0.73$ & 77 & 0.70 & 1.44 \\
\hline
\end{tabular}

Scaling coefficient (a) calculated as principal axis; confidence interval calculation including $N$. $s_{11}$ and $s_{22}$ from Jolicoeus $\{1973$ ).

clearly that the differences between, for example, allometric scaling in the central and peripheral cheek teeth are both real and significant.

The sums of upper and lower cheek teeth have scaling coefficients of 0.62 and 0.69 , respectively, indicating that lower cheek teeth as a group scale significantly higher than upper cheek teeth do. Furthermore, lower cheek teeth as a group scale significantly higher than upper cheek teeth at some individual positions, and upper cheek teeth as a group scale significantly lower than lower cheek teeth at some individual positions. In other words, no single tooth or even group of contiguous cheek teeth is adequate to characterize allometric scaling in the primate dentition.

These results are interesting with respect to the question of whether primate teeth scale geometrically or metabolically. Both of these models, geometric and metabolic, are plotted as a horizontal line at the appropriate level (0.67 and 0.75 , respectively) in Figure 3. Upper incisors and the upper canine clearly approximate metabolic scaling more closely than they do geometric scaling. $P^{2}$ has such a broad confidence interval that it does not really fit one model better than the other. $\mathrm{P}^{3}$ and $\mathrm{M}^{2}$ both approximate geometric scaling and both are significantly below metabolic scaling. $\mathrm{P}^{4}$ and $\mathrm{M}^{1}$ scale significantly below even the geometric model, whereas scaling in $\mathrm{M}^{3}$ conforms closely to that predicted by the metabolic model. Scaling in $\mathbf{M}^{3}$ is significantly greater than that predicted by the geometric model.

In the lower dentition, scaling of $I_{1}$ is ambiguous, since the $95 \%$ confidence interval includes both the geometric and metabolic models. $\mathrm{I}_{2}$ appears to scale approximately geometrically. The lower canine appears to scale metabolically. $P_{2}$ approximates metabolic scaling as well but, like $\mathrm{P}^{2}$, it has such a broad confidence interval that neither model can be ruled out. $P_{3}, M_{2}$, and $M_{3}$ conform to the metabolic model, with scaling coefficients significantly higher than predicted by the geometric model, but $\mathrm{P}_{4}$ and $\mathrm{M}_{1}$ conform to the geometric rather than metabolic scaling model.

Upper cheek teeth as a group have an allometric coefficient much smaller than that predicted by the geometric scaling model. The upper limit of the $95 \%$ confidence interval for this coefficient is 0.67 , which is the expected value given geometric scaling, indicating that the difference is statistically significant. Lower cheek teeth as a group approximate geometric scaling. Both summed upper and summed 

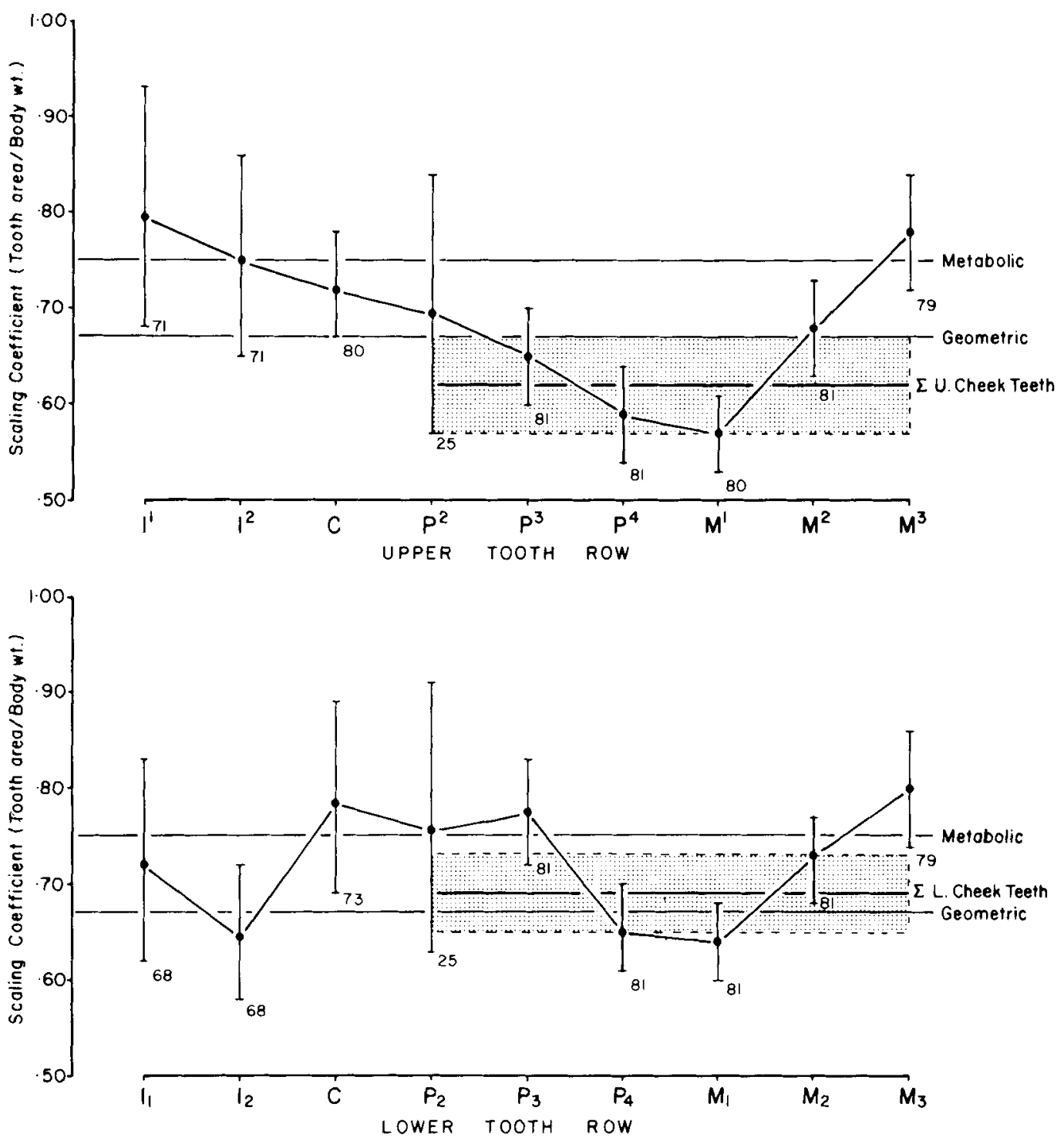

Fig. 3. Summary diagrams showing patterns of allometric scaling of tooth crown area and body weight in generalized primates. Upper and lower diagrams show scaling coefficients (solid circles) at each tooth position in the upper and lower dentition, respectively, with associated $95 \%$ confidence intervals (vertical bars). Heavy horizontal lines show scaling coefficients of summed crown areas of upper and lower cheek teeth, respectively, with stippled horizontal bars enclosing $95 \%$ confidence intervals of scaling coefficients of summed tooth areas. Note that in the upper dentition allometric scaling of anterior and posterior teeth exceeds metabolic scaling $(0.75)$, while central cheek teeth $\left(\mathrm{P}^{3}-\mathrm{M}^{2}\right)$ are at or below geometric scaling. In the lower dentition incisors approximate geometric scaling while anterior and posterior cheek teeth exceed metabolic scaling and central cheek teeth $\left(\mathrm{P}_{4}-\mathrm{M}_{1}\right)$ are at or below geometric scaling. Note also that lower cheek teeth scale consistently higher than upper cheek teeth.

lower cheek teeth scale significantly below metabolic scaling in generalized primates.

The overall effect of the observed patterns of allometric scaling of tooth area and body weight can be visualized by comparing the dentitions of small, medium, and large primates shown in Figure 4, which are drawn to approximately the same palatal length. Here 


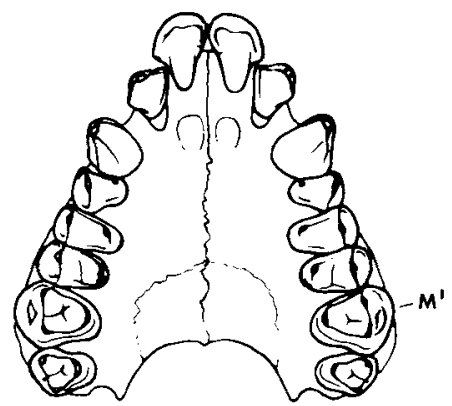

A

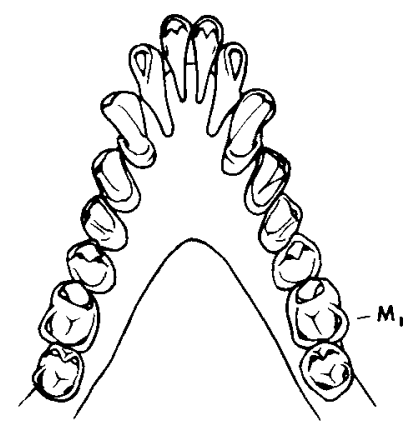

$\mathrm{B}$

Callithrix

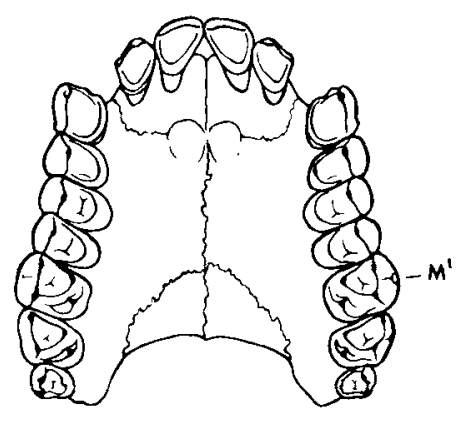

C

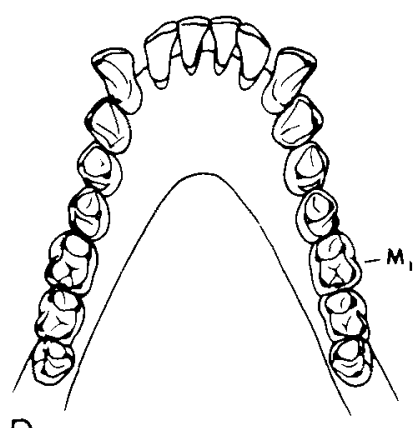

D

Saimiri

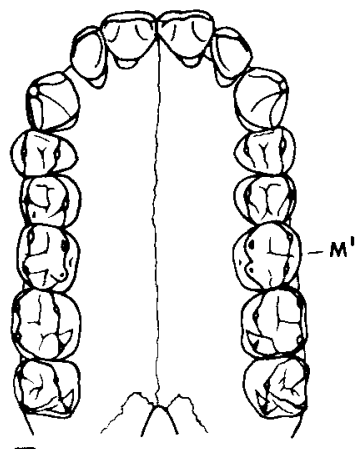

E

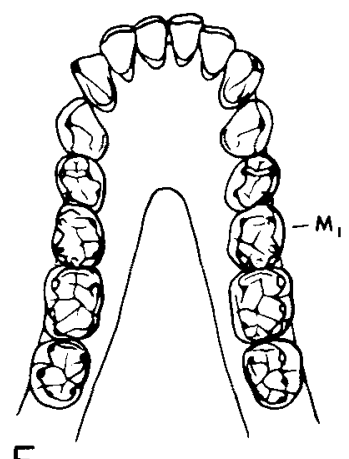

$\mathrm{F}$

Gorilla

Fig. 4. Comparison of upper and lower dentitions of small (Callithrix, A and B), medium (Saimiri, C and D), and large (Gorilla, $\mathrm{E}$ and $\mathrm{F}$ ) primates, all drawn at approximately the same palatal length to illustrate in a very general way how the dentition changes with changing body size. Note progressively more squared palatal shape in the sequence from Callithrix to Gorilla, corresponding to strong positive allometry of upper incisor size. Note small $\mathbf{M}_{2}^{2}$ and absence of $\mathbf{M}_{3}^{3}$ in Callithrix, small size of these teeth in Saimiri, and relative enlargement of these teeth in Gorilla, corresponding to strong positive allometry of posterior cheek teeth. In addition, note discrepancy in size of upper and lower cheek teeth in Callithrix and Saimiri compared with the more nearly equal size of these teeth in Gorilla, corresponding to the more positive allometry of lower cheek teeth compared with upper cheek teeth.

upper and lower dentitions of Callithrix (350-400 gm), Saimiri (600-700 gm), and Gorilla $(100-150 \mathrm{~kg})$ are compared to illustrate general trends of allometric change in incisors and cheek teeth.

The observation that teeth in three out of four incisor positions scale in excess of geometric scaling means that larger primates should have relatively larger incisors than smaller primates, and vice versa. Small primates like Callithrix tend to have V-shaped maxillary and mandibular tooth rows, whereas larger primates like Gorilla have a rectangular dental arcade with more nearly parallel tooth rows. If upper incisors scale at a higher rate than lower incisors, then larger primates should have a disproportionately broader upper incisor row compared to the lower incisor row. In addition, as Hylander (1975) has shown, diet has an important influence on relative incisor size that is independent of body size differences.

The pattern of high allometric coefficients at the front and back of the cheek tooth row, grading into lower coefficients in the center of the cheek tooth row, indicates that larger primates have disproportionately larger premolars and last molars compared to the size of their central cheek teeth. Additional cheek tooth area in larger primates is added at the ends of the cheek tooth row. For example, Gorilla tends to have large second and third molars and, conversely, Callithrix has reduced second 


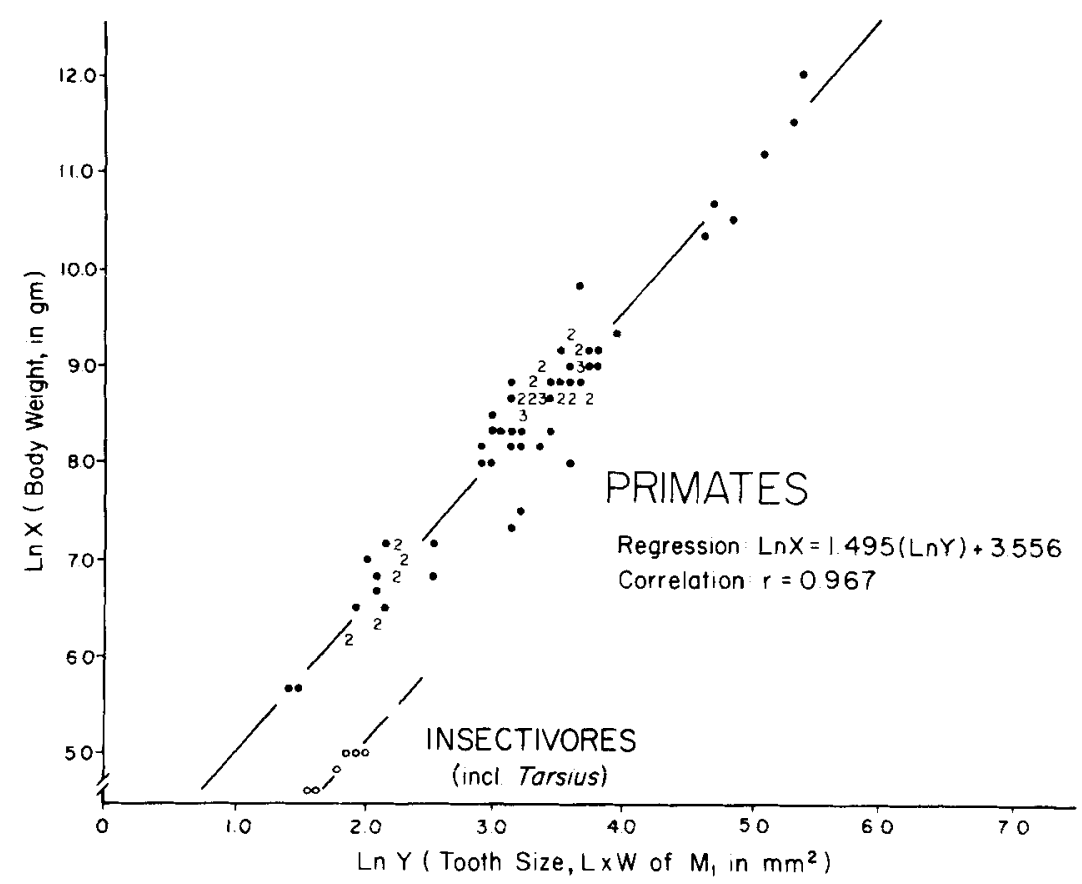

Fig. 5. Regression of $\ln$ body weight on $\ln$ crown area of $M_{1}$ in generalized primates. This regression can be used to estimate body weights of fossil primates known only from dental remains (Tables 3-5). Note that tree shrews and Tarsius, like other insectivores, have smaller body weights for their tooth size than generalized primates do, indicating that this regression will not predict body weights of specialized insectivorous primates with acceptable accuracy.

molars and no third molars. Tooth size reduction takes place at the ends of the cheek tooth series when primates become smaller.

Small primates tend to have narrower lower cheek teeth than upper cheek teeth, and the fact that lower cheek teeth scale at a higher rate than upper cheek teeth means that lower and upper premolars and molars should become more isometric with increasing body size; i.e., the differences in size between upper and lower cheek teeth should be diminished at larger body sizes. This trend is nicely illustrated by comparing the relative size of upper and lower molars in Callithrix or Saimiri with those in Gorilla (Fig. 4).

\section{PREDICTING BODY SIZE FROM TOOTH SIZE IN GENERALIZED FOSSIL، PRIMATES}

The same measurements used to study allometric scaling of tooth size and body size in generalized primates can be used to construct a series of equations for predicting body weight from tooth size. The problem here is slightly different than that discussed in the previous section. Instead of looking at the structural relationship of two variables, in this section we shall attempt to use one variable (tooth size) to predict the other (body weight). Whereas the principal axis (or major axis) is the best representation of the covariation of two variables, a linear regression of body size on tooth size is most appropriate for the prediction problem (Fig. 5).

Results of the regression of body weight on tooth size at each tooth position in the dentition of generalized primates are summarized in Table 3. Given the crown area ( $Y$ ) of any tooth in the dentition, it is possible to substitute this value into Equation 1 of Table 3 and then solve for body weight $(X)$ using values of $a$ and $\ln b$ for the appropriate tooth. ${ }^{1}$ The $95 \%$ confidence

'Note that in our least squares regression equations the independent variable (tooth area) is termed $Y$ and the dependent variable (body weight) is termed $X$. We have not followed standard practice in this instance in order to maintain consistency with the previous discussion of dental allometry. 
TABLE 3. Equations and critical values for predicting body weight from tooth size in generalized primates.

(1) $\ln \mathrm{X}=\ln \mathrm{b}+\mathrm{a} \ln \mathrm{Y}$

or in exponential form; Body weight $=\mathrm{X}=\exp [\ln \mathrm{b}+\mathrm{a} \ln \mathrm{Y}]=\mathrm{b} \mathrm{Y}^{\mathrm{a}}$

(2) $95 \%$ Confidence interval for $\ln \mathrm{X}=\ln \mathrm{X} \pm 1.96 \sqrt{C_{1}+\left(\ln \mathrm{Y}-\overline{\left.C_{2}\right)^{2}} \overline{\left(C_{3}\right.}\right)}$

or in exponential form: $95 \%$ confidence interval for $\mathrm{X}=\exp \left[\ln \mathrm{X} \pm 1.96 \sqrt{\left.C_{1}+\left(\ln \mathrm{Y}-\overline{C_{2}}\right)^{2}\left(C_{3}\right)\right]}\right.$

\begin{tabular}{|c|c|c|c|c|c|c|}
\hline $\begin{array}{l}\text { Tooth } \\
\text { Position }\end{array}$ & $\begin{array}{c}\text { Correlation } \\
(r)\end{array}$ & $\begin{array}{c}\text { Slope } \\
(a)\end{array}$ & $\begin{array}{c}\text { Intercept } \\
(L n b)\end{array}$ & $C_{1}$ & $C_{2}$ & $C_{3}$ \\
\hline \multicolumn{7}{|c|}{ UPPER DENTITION } \\
\hline $\mathrm{I}^{1}$ & 0.835 & 1.01 & 5.42 & 0.00506 & 3.1402 & 0.00625 \\
\hline $\mathrm{I}^{2}$ & 0.858 & 1.10 & 5.64 & 0.00440 & 2.6815 & 0.00611 \\
\hline $\mathrm{C}^{1}$ & 0.947 & 1.29 & 4.08 & 0.00193 & 3.3692 & 0.00239 \\
\hline $\mathrm{P}^{2}$ & 0.902 & 1.25 & 4.38 & 0.00712 & 2.2620 & 0.01439 \\
\hline $\mathrm{P}^{3}$ & 0.943 & 1.42 & 4.18 & 0.00203 & 3.0002 & 0.00309 \\
\hline $\mathrm{P}^{4}$ & 0.934 & 1.53 & 3.64 & 0.00232 & 3.1163 & 0.00422 \\
\hline $\mathrm{M}^{\mathrm{I}}$ & 0.946 & 1.62 & 2.72 & 0.00191 & 3.5074 & 0.00381 \\
\hline $\mathbf{M}^{2}$ & 0.945 & 1.37 & 3.49 & 0.00194 & 3.6026 & 0.00275 \\
\hline $\mathbf{M}^{3}$ & 0.947 & 1.20 & 4.40 & 0.00182 & 3.3944 & 0.00211 \\
\hline$\Sigma$ cheek teeth & 0.949 & 1.50 & 0.94 & 0.00184 & 5.0172 & 0.00322 \\
\hline \multicolumn{7}{|c|}{ LOWER DENTITION } \\
\hline $\mathrm{I}_{1}$ & 0.854 & 1.13 & 5.60 & 0.00464 & 2.6981 & 0.00696 \\
\hline$I_{2}$ & 0.921 & 1.38 & 4.86 & 0.00261 & 2.7464 & 0.00500 \\
\hline $\mathbf{C}_{1}$ & 0.882 & 1.09 & 5.07 & 0.00382 & 3.2353 & 0.00465 \\
\hline $\mathrm{P}_{2}$ & 0.913 & 1.18 & 4.49 & 0.00635 & 2.3081 & 0.01109 \\
\hline $\mathrm{P}_{3}$ & 0.954 & 1.21 & 4.65 & 0.00164 & 3.1154 & 0.00180 \\
\hline $\mathrm{P}_{4}$ & 0.955 & 1.44 & 4.20 & 0.00159 & 2.9375 & 0.00244 \\
\hline $\mathrm{M}_{1}$ & 0.967 & 1.49 & 3.55 & 0.00119 & 3.2151 & 0.00192 \\
\hline $\mathrm{M}_{2}$ & 0.968 & 1.31 & 3.92 & 0.00113 & 3.4244 & 0.00141 \\
\hline $\mathrm{M}_{3}$ & 0.947 & 1.17 & 4.43 & 0.00182 & 3.4601 & 0.00200 \\
\hline$\Sigma$ cheek teeth & 0.964 & 1.38 & 1.67 & 0.00135 & 4.9105 & 0.00195 \\
\hline
\end{tabular}

$\mathrm{X}=$ body weight $(\mathrm{gm}): \mathrm{Y}=$ tooth crown area (length $\times$ width, in mm) $\mathrm{a}=$ exponent, or slope of ln transformed dat $\mathrm{a}$; $\mathrm{b}=$ constant, or $X$-intercept of $\ln$ transformed data; $C_{1}, C_{2}$. and $C_{3}$ are critical values for calculating the $95 \%$ confidence interval of 1 transformed data (Draper and Smith, 1966).

Note: Slopes and intercepts are provided for computation of a predicted $\ln$ mean body weight (ln X) from a particular In tooth crown area (In $Y$ ! using Equation 1. Confidence limits are obtained by substituting both $\ln X$ and $\ln Y$ in Equation 2 with appropriate values for $C_{1}$ $C_{2}$, and $C_{3}$, where $C_{1}=$ mean square error [MSE] $N, C_{2}=\overline{\mathrm{Y}}$, and $C_{3}=\mathrm{MSE} / \Sigma\left(\mathrm{Y}_{\mathrm{i}}-\overline{\mathrm{Y}}\right)^{2}$. The value $1.96\left(\mathrm{Z}_{\text {.grs }}\right)$, taken from a normal table, is used throughout rather than $t(.975, \mathrm{~N}-2)$ because $\mathrm{N}$ is large in each case.

interval for this estimated body weight can be determined by substituting appropriate values of $C_{1}, C_{2}$, and $C_{3}$ into Equation 2 of Table 3.

The areas of $M_{1}$ and $M_{2}$ are most highly correlated with body size, and measurements of these teeth are consequently the best to use in predicting body weight from tooth size. It should be emphasized that the resulting predicted body weight, even if based on a single specimen, is a predicted average weight for the species represented. Obviously, the larger the number of teeth measured at a given position, the better the final prediction of body weight for the species under study. However, the low correlation of tooth size and body size within species (e.g., Garn and Lewis, 1958) precludes using tooth size to estimate and compare body weights of individuals in the same population or species. Measurement of as many different dental, cranial, and postcranial dimensions of a skeleton as available will contribute to the accuracy of the final prediction, but for many fossil primates cranial and postcranial elements are unknown and any estimate of body size necessarily requires a prediction based on tooth size. Furthermore, the marginal contribution of each additional measurement in altering the final prediction diminishes rapidly after two or three variates are considered.

As an example, we have predicted the body weight of the Oligocene anthropoid Aegyptopithecus zeuxis based on the size of its teeth (Table 4). This particular example is useful because Gingerich (1977a) and Kay and Simons (1980) attempted to estimate the body weight of Aegyptopithecus previously, based on tooth size, cranial size, and the size of postcranial elements, furnishing some basis for comparison with our results. Depending on the measurements used and the procedure employed, lower cheek teeth yield estimates of 
TABLE 4. Comparison of six methods of estimating the body weight of Aegyptopithecus zeuxis

(1) Body weight estimated from the size of $M_{1}$ in the holotype only.

$M_{1}$ measures $6.0 \mathrm{~mm}$ in length and $5.3 \mathrm{~mm}$ in width: $\mathrm{L} \times \mathrm{W}$ of $\mathrm{M}_{1}=31.8$ and $\ln Y=3.46$.

Body weight $X=6,030 \mathrm{gm}(95 \%$ confidence interval $=5,615$ to $6,475 \mathrm{gm})$.

(2) Body weight estimated successively and cumulatively from the size of $M_{1}, M_{2}$, and $P_{4}$ in the holotype.

$M_{1}$ yields a body weight estimate of $6,030 \mathrm{gm}$ (see above).

$M_{2}$ measures $6.4 \mathrm{~mm}$ in length and $6.4 \mathrm{~mm}$ in width: $\mathrm{L} \times \mathrm{W}$ of $\mathrm{M}_{2}=41.0$ and $\ln Y=3.71$.

Body weight $X=6,525 \mathrm{gm}(95 \%$ confidence interval $=6,085$ to $6,995 \mathrm{gm})$.

Average of estimates based on $M_{1}$ and $M_{2}=6,280 \mathrm{gm}$.

$P_{4}$ measures $4.9 \mathrm{~mm}$ in length and $4.1 \mathrm{~mm}$ in width: $\mathrm{L} X W$ of $P_{4}=20.1$ and $\ln Y=3.00$

Body weight $X=5,015 \mathrm{gm}(95 \%$ confidence interval $=4,635$ to $5,425 \mathrm{gm})$.

Average of estimates based on $P_{4}, M_{1}$, and $M_{2}=5,855 \mathrm{gm}$.

(3) Body weight estimated from the means of length and width measurements of seven specimens preserving $M_{1}$ from Quarry I (Kay et al., 1981).

Average sample $M_{1}$ length is $5.86 \mathrm{~mm}$ and average $M_{1}$ width is $5.43 \mathrm{~mm}$ : average $\mathrm{L} \times \mathrm{W}$ of $\mathrm{M}_{1}=31.8$ and $\ln Y=3.46$. Body weight $X=6,035 \mathrm{gm}(95 \%$ confidence interval $=5,620$ to $6,480 \mathrm{gm})$.

(4) Body weight estimated from the means of length and width measurements of 3 specimens preserving $M^{1}$ from Quarry I (Kay et al., 1981).

Average sample $M^{1}$ length is $5.80 \mathrm{~mm}$ and average $M^{1}$ width is $7.30 \mathrm{~mm}$ :

Average $\mathrm{L} \times \mathrm{W}$ of $\mathrm{M}^{1}=\mathbf{4 2 . 3}$ and $\ln Y=3.74$.

Body weight $X=6,495 \mathrm{gm}(95 \%$ confidence interval $=5,935$ to $7,110 \mathrm{gm}$ ).

Average of weights based on $M^{1}$ and $M_{1}$ from Quarry $I=6,265 \mathrm{gm}$.

(5) Body weight estimated from ulna approximately the size of that of Alouatta or Presbytis cristatus (Fleagle et al., 1975).

The average body weight of Alouatta sp. and Presbytis cristatus ranges from about 6,350 to $8,350 \mathrm{gm}$ (see Table 1).

(6) Body weights estimated from cranial dimensions of one known skull.

Regressions of cranial dimensions in 16 Old and New World monkey species give body weight estimates in

Aegyptopithecus ranging from $2,560 \mathrm{gm}$ to $10,040 \mathrm{gm}$. The average for all 7 dimensions used is $5,280 \mathrm{gm}$ (Kay and Simons, 1980).

Methods 1-4 make use of Equations 1 and 2 in Table 3. Methods 5 and 6, based on posteranial and cranial dimensions, are included for comparison.

$6,030 \mathrm{gm}, 5,855 \mathrm{gm}$, or $6,035 \mathrm{gm}$ for the average body weight of Aegyptopithecus zeuxis. Upper first molars yield an estimate of $6,495 \mathrm{gm}$ as the average body weight of Aegyptopithecus. For comparison, the estimate from the size of one known ulna is about $7,350 \mathrm{gm}$, and the estimate based on cranial dimensions of the one known skull is 5,280 gm (Table 4). The estimates of body size in Aegyptopithecus based on tooth size are well within the range of estimates derived from the size of known cranial and postcranial elements, indicating that the estimates based on tooth size are reasonable.

For reference purposes we estimated the body weights of a number of representative species of generalized fossil primates based on their tooth size. These are listed in Table 5. Plesiadapiform primates are not included because of their unusually specialized dentitions. Tarsiiform Omomyidae are not included because they appear, like Tarsius, to have larger cheek teeth for their body weight than generalized primates (Fig. 5; see also
Gingerich, 1981). Fifteen species of lemuriform Adapidae are included in Table 5, and these range in size from an estimated body weight of about $110 \mathrm{gm}$ in Anchomomys gaillardi to as much as $10,730 \mathrm{gm}$ in Adapis magnus. It should be noted that upper molars $\left(M^{1}\right)$ consistently give higher body weight estimates than lower molars $\left(M_{1}\right)$ when both are preserved in the same species sample. In Adapis and Sivaladapis this discrepancy is as much as 50-60\%. Both genera are of large body size, with broad upper molars and narrow lower molars, suggesting that perhaps tooth size in large Eocene folivorous primates did not scale exactly as it does in extant species (see discussion below).

South American Oligocene and Miocene Ceboidea and African Oligocene Parapithecidae and Miocene Cercopithecidae are presently known only from very small samples. This makes estimation of their body weights difficult since, in most cases, estimates based on upper teeth cannot be compared with those derived from lower teeth. 
TABLE 5. Estimated body weights of some representative species of Eocene, Oligocene, and Miocene fossil primates, based on the regression coefficients given in Table 3. Tooth size in ln (length $\times$ width) for $M^{\prime}$ or $M_{1}$, with sample size n, as indicated. Original measurements in $\mathrm{mm}$.

\begin{tabular}{|c|c|c|c|c|c|}
\hline Genus and species & Age & $\begin{array}{c}\text { Locality } \\
\text { (reference) }\end{array}$ & $\begin{array}{c}\text { Tooth size } \\
\text { In (length } x \\
\text { width) }\end{array}$ & $\begin{array}{c}\text { Estimated } \\
\text { weight } \\
\text { (gm) }\end{array}$ & $\begin{array}{l}95 \% \\
\text { Confidence } \\
\text { interval } \\
\end{array}$ \\
\hline $\begin{array}{l}\text { North American Adapidae } \\
\text { Cantius ralstoni }\end{array}$ & $\begin{array}{l}\text { Early } \\
\text { Eocene }\end{array}$ & $\begin{array}{l}\text { SC-4, Clarks Fork Basin, } \\
\text { Wyoming (Gingerich and } \\
\text { Simons, 1977) }\end{array}$ & $\begin{array}{l}\mathrm{M}^{1}=2.94(\mathrm{n}=4) \\
\mathrm{M}_{1}=2.44(\mathrm{n}=16)\end{array}$ & $\begin{array}{l}1,775 \\
1,320\end{array}$ & $\begin{array}{l}1,590-1,985 \\
1,200-1,455\end{array}$ \\
\hline Cantius abditus & $\begin{array}{l}\text { Early } \\
\text { Eocene }\end{array}$ & $\begin{array}{l}\text { YM-45, Bighorn Basin, } \\
\text { Wyoming (Gingerich and } \\
\text { Simons, 1977) }\end{array}$ & $\begin{array}{l}\mathbf{M}^{1}=- \\
\mathbf{M}_{1}=3.01(\mathrm{n}=13)\end{array}$ & $\overline{3,090}$ & $2,875-3,310$ \\
\hline Smilodectes gracilis & $\begin{array}{l}\text { Middle } \\
\text { Eocene }\end{array}$ & $\begin{array}{l}\text { Grizzly Buttes, Bridger, } \\
\text { Basin, Wyoming (Gingerich } \\
\text { 1979) }\end{array}$ & $\begin{array}{l}\mathrm{M}^{1}=- \\
\mathrm{M}_{1}=2.74(\mathrm{n}=5)\end{array}$ & - & $\stackrel{-}{1,905-2,235}$ \\
\hline Notharctus tenebrosus & $\begin{array}{l}\text { Middle } \\
\text { Eocene }\end{array}$ & $\begin{array}{l}\text { Blacks Fork, Bridger Basin } \\
\text { Wyoming (Gingerich, 1979) }\end{array}$ & $\begin{array}{l}\mathrm{M}^{1}=- \\
\mathrm{M}_{1}=3.10(\mathrm{n}=20)\end{array}$ & - & $\stackrel{-}{-}, 295-3,780$ \\
\hline Notharctus robustior & $\begin{array}{l}\text { Middle } \\
\text { Eocene }\end{array}$ & $\begin{array}{l}\text { Henrys Fork, Bridger Basin } \\
\text { Wyoming (Gingerich, 1979) }\end{array}$ & $\begin{array}{l}\mathrm{M}^{1}=- \\
\mathrm{M}_{1}=3.58(\mathrm{n}=26)\end{array}$ & - & $6,695-7,775$ \\
\hline Mahgarita stevensi & $\begin{array}{l}\text { Late } \\
\text { Eocene }\end{array}$ & $\begin{array}{l}\text { Typee Canyon, Brewster Co., } \\
\text { Texas (Wilson and Szalay, } \\
\text { 1976) }\end{array}$ & $\begin{array}{l}\mathrm{M}^{1}=2.79(\mathrm{n}=1) \\
\mathrm{M}_{1}=2.25(\mathrm{n}=1)\end{array}$ & $\begin{array}{r}1,395 \\
995\end{array}$ & $\begin{array}{r}1,230-1,575 \\
890-1,110\end{array}$ \\
\hline $\begin{array}{l}\text { European Adapidae } \\
\text { Cantius eppsi }\end{array}$ & $\begin{array}{l}\text { Early } \\
\text { Eocene }\end{array}$ & $\begin{array}{l}\text { Abbey Wood (Kent), England } \\
\text { (Gingerich, unpublished) }\end{array}$ & $\begin{array}{l}\mathrm{M}^{\prime}=2.75(\mathrm{n}=1) \\
\mathrm{M}_{1}=2.30(\mathrm{n}=2)\end{array}$ & $\begin{array}{l}1,305 \\
1,070\end{array}$ & $\begin{array}{r}1,150-1,480 \\
965-1,190\end{array}$ \\
\hline Periconodon huerzeleri & $\begin{array}{l}\text { Middle } \\
\text { Eocene }\end{array}$ & $\begin{array}{l}\text { Buchsweiler (Bas-Rhin), } \\
\text { France (Gingerich, unpubl.) }\end{array}$ & $\begin{array}{l}\mathrm{M}^{\prime}=2.26(\mathrm{n}=1) \\
\mathrm{M}_{1}=1.85(\mathrm{n}=4)\end{array}$ & $\begin{array}{l}590 \\
550\end{array}$ & $\begin{array}{l}495-705 \\
475-630\end{array}$ \\
\hline Protoadapis klatti & $\begin{array}{l}\text { Middle } \\
\text { Eocene }\end{array}$ & $\begin{array}{l}\text { Geiseltal, East Germany } \\
\text { (Gingerich, unpublished) }\end{array}$ & $\begin{array}{l}\mathrm{M}^{1}=2.95(\mathrm{n}=2) \\
\mathrm{M}_{1}=2.57(\mathrm{n}=3)\end{array}$ & $\begin{array}{l}1,805 \\
1,600\end{array}$ & $\begin{array}{l}1,620-2,015 \\
1,465-1,750\end{array}$ \\
\hline Anchomomys gaillardi & $\begin{array}{l}\text { Late } \\
\text { Eocene }\end{array}$ & $\begin{array}{l}\text { Lissieu (Rhone), France } \\
\text { (Gingerich, unpublished) }\end{array}$ & $\begin{array}{l}\mathrm{M}^{\prime}=1.38(\mathrm{n}=1) \\
\mathrm{M}_{1}=0.77(\mathrm{n}=2)\end{array}$ & $\begin{array}{l}140 \\
110\end{array}$ & $\begin{array}{r}105-190 \\
85-140\end{array}$ \\
\hline Adapis sudrei & $\begin{array}{l}\text { Late } \\
\text { Eocene }\end{array}$ & $\begin{array}{l}\text { Robiac (Gard), France } \\
\text { (Gingerich, 1977b) }\end{array}$ & $\begin{array}{l}\mathrm{M}^{\prime}=3.20(\mathrm{n}=5) \\
\mathrm{M}_{1}=2.62(\mathrm{n}=12)\end{array}$ & $\begin{array}{l}2,710 \\
1,725\end{array}$ & $\begin{array}{l}2,465-2,975 \\
1,585-1,880\end{array}$ \\
\hline Adapis magnus & $\begin{array}{l}\text { Late } \\
\text { Eocene }\end{array}$ & $\begin{array}{l}\text { Euzet (Gard), France } \\
\text { (Gingerich, 1977c) }\end{array}$ & $\begin{array}{l}\mathrm{M}^{1}=4.05(\mathrm{n}=7) \\
\mathrm{M}_{\mathrm{t}}=3.51(\mathrm{n}=23)\end{array}$ & $\begin{array}{r}10,730 \\
6,500\end{array}$ & $\begin{array}{l}9,630-11,955 \\
6.050-6,990\end{array}$ \\
\hline $\begin{array}{l}\text { African Adapidae } \\
\text { Oligopithecus savagei }\end{array}$ & Oligocene & $\begin{array}{l}\text { Quarry E (Fayum), Egypt } \\
\text { (Gingerich, unpublished) }\end{array}$ & $\begin{array}{l}\mathrm{M}^{1}=- \\
\mathrm{M}_{1}=2.50(\mathrm{n}=1)\end{array}$ & $\overline{1,455}$ & $1,325-1,590$ \\
\hline $\begin{array}{l}\text { Asian Adapidae } \\
\text { Sivaladapis nagrii }\end{array}$ & $\begin{array}{l}\text { Late } \\
\text { Miocene }\end{array}$ & $\begin{array}{l}\text { Haritalyangar, India } \\
\text { (Gingerich and Sahni, } \\
\text { unpublished) }\end{array}$ & $\begin{array}{l}\mathrm{M}^{1}=3.76(\mathrm{n}=3) \\
\mathrm{M}_{1}=3.25(\mathrm{n}=5)\end{array}$ & $\begin{array}{l}6,710 \\
4,415\end{array}$ & $\begin{array}{l}6,125-7,350 \\
4,125-4,725\end{array}$ \\
\hline Indraloris lulli & $\begin{array}{l}\text { Late } \\
\text { Miocene }\end{array}$ & $\begin{array}{l}\text { Haritaly angar, India } \\
\text { (Gingerich and Sahni, } \\
\text { unpublished) }\end{array}$ & $\begin{array}{l}\mathrm{M}^{1}=- \\
\mathrm{M}_{1}=3.19(\mathrm{n}=1)\end{array}$ & $\overline{4,035}$ & $\overrightarrow{3,770-4,320}$ \\
\hline $\begin{array}{l}\text { South American Ceboidea } \\
\text { Branisella boliviana }\end{array}$ & $\begin{array}{l}\text { Early } \\
\text { Oligocene }\end{array}$ & $\begin{array}{l}\text { Salla, Bolivia } \\
\text { (Hoffstetter, 1969) }\end{array}$ & $\begin{array}{l}\mathrm{M}^{1}=2.67(\mathrm{n}=1) \\
\mathrm{M}_{1}=-\end{array}$ & $\begin{array}{l}1,150 \\
-\end{array}$ & $\begin{array}{c}1,005-1,310 \\
-\end{array}$ \\
\hline patagonicus & $\begin{array}{l}\text { Early } \\
\text { Miocene }\end{array}$ & $\begin{array}{l}\text { Rio Gallegos, Argentina } \\
\text { (Hershkovitz, 1970) }\end{array}$ & $\begin{array}{l}\mathbf{M}^{1}=- \\
\mathbf{M}_{1}=2.89(\mathbf{n}=1)\end{array}$ & $\overrightarrow{2,580}$ & $\frac{-}{2,395-2,780}$ \\
\hline Neosaimiri fieldsi & $\begin{array}{l}\text { Middle } \\
\text { Miocene }\end{array}$ & $\begin{array}{l}\text { La Venta (Huila), } \\
\text { Colombia (Stirton, 1951) }\end{array}$ & $\begin{array}{l}\mathrm{M}^{1}=- \\
\mathrm{M}_{1}=2.13(\mathrm{n}=1)\end{array}$ & - & $\frac{-}{740-935}$ \\
\hline
\end{tabular}


TABLE 5. Estimated body weights of some representative species of Eocene, Oligocene, and Miocene fossil primates, based on the regression coefficients given in Table 3. Tooth size in ln (length $\times$ width) for $M^{1}$ or $M_{1}$, with sample size n, as indicated. Original measurements in $\mathrm{mm}$ (continued)

\begin{tabular}{|c|c|c|c|c|c|}
\hline Genus and species & Age & $\begin{array}{c}\text { Locality } \\
\text { (reference) }\end{array}$ & $\begin{array}{l}\text { Tooth size } \\
\text { ln (length } \times \\
\text { width) }\end{array}$ & $\begin{array}{l}\text { Estimated } \\
\text { weight } \\
\text { (gm) }\end{array}$ & $\begin{array}{l}95 \% \\
\text { Confidence } \\
\text { interval }\end{array}$ \\
\hline Cebupithecia sarmientoi & $\begin{array}{l}\text { Middle } \\
\text { Miocene }\end{array}$ & $\begin{array}{l}\text { La Venta (Huila), } \\
\text { Colombia (Stirton, 1951) }\end{array}$ & $\begin{array}{l}M^{1}=2.96(n=1) \\
M_{1}=2.75(n=1)\end{array}$ & $\begin{array}{l}1,835 \\
2,095\end{array}$ & $\begin{array}{l}1,645-2,045 \\
1,935-2,270\end{array}$ \\
\hline Stirtonia tatacoensis & $\begin{array}{l}\text { Middle } \\
\text { Miocene }\end{array}$ & $\begin{array}{l}\text { La Venta (Huila), } \\
\text { Colombia (Stirton, 1951) }\end{array}$ & $\begin{array}{l}M^{1}=- \\
M_{\mathbf{s}}=3.37(\mathrm{n}=1)\end{array}$ & $\overline{5,280}$ & $\frac{-}{4,925-5,655}$ \\
\hline $\begin{array}{l}\text { African Parapithecidae } \\
\text { Apidium moustafai }\end{array}$ & Oligocene & $\begin{array}{l}\text { Quarry G (Fayum), Egypt } \\
\text { (Simons, 1962) }\end{array}$ & $\begin{array}{l}\mathrm{M}^{1}=- \\
\mathrm{M}_{1}=2.32(\mathrm{n}=3)\end{array}$ & $\overline{1,105}$ & $995-1,225$ \\
\hline Apidium phiomense & Oligocene & $\begin{array}{l}\text { Fayum, Egypt (Gingerich, } \\
\text { 1978) }\end{array}$ & $\begin{array}{l}\mathrm{M}^{1}=- \\
\mathrm{M}_{1}=2.60(\mathrm{n}=2)\end{array}$ & - & $\frac{-}{1,535-1,830}$ \\
\hline Simonsius grangeri & Oligocene & $\begin{array}{l}\text { Quarry I (Fayum), Egypt } \\
\text { (Simons, 1974) }\end{array}$ & $\begin{array}{l}\mathrm{M}^{1}=- \\
\mathrm{M}_{1}=2.99(\mathrm{n}=6)\end{array}$ & $\overrightarrow{2,995}$ & $2,790-3,215$ \\
\hline $\begin{array}{l}\text { African Cercopithecidae } \\
\text { Victoriapithecus } \\
\text { macinnesi }\end{array}$ & $\begin{array}{l}\text { Early } \\
\text { Miocene }\end{array}$ & $\begin{array}{l}\text { Rusinga Is., Kenya (von } \\
\text { Koenigswald, 1969) }\end{array}$ & $\begin{array}{l}\mathrm{M}^{1}=\overrightarrow{ } \\
\mathrm{M}_{1}=3.33(\mathrm{n}=1)\end{array}$ & $\overline{4.975}$ & $4,640-5,325$ \\
\hline Prohylobates tandyi & $\begin{array}{l}\text { Early } \\
\text { Miocene }\end{array}$ & $\begin{array}{l}\text { Wadi Moghara, Egypt } \\
\text { (Simons, 1969) }\end{array}$ & $\begin{array}{l}M^{1}=- \\
M_{1}=3.55(n=3)\end{array}$ & $-\overline{6,900}$ & $\frac{-}{6,410-7,430}$ \\
\hline $\begin{array}{l}\text { European Oreopithecidae } \\
\text { Oreopithecus bambolii }\end{array}$ & $\begin{array}{l}\text { Late } \\
\text { Miocene }\end{array}$ & $\begin{array}{l}\text { Grosseto Lignite (Tuscany). } \\
\text { Italy (Hürzeler, 1958) }\end{array}$ & $\begin{array}{l}\mathrm{M}^{1}=4.27(\mathrm{n}=2) \\
\mathrm{M}_{1}=4.06(\mathrm{n}=2)\end{array}$ & $\begin{array}{l}15,325 \\
14,755\end{array}$ & $\begin{array}{l}13,510-17,385 \\
13,360-16,295\end{array}$ \\
\hline $\begin{array}{l}\text { African Hominoidea } \\
\text { Propliopithecus } \\
\text { chirobates }(?=P . \\
\text { haeckeli) }\end{array}$ & Oligocene & $\begin{array}{l}\text { Quarry I (Fayum), Egypt } \\
\text { (Kay et al., 1981) }\end{array}$ & $\begin{array}{l}\mathrm{M}^{1}=3.47(\mathrm{n}=3) \\
\mathrm{M}_{1}=3.17(\mathrm{n}=6)\end{array}$ & $\begin{array}{l}4,195 \\
3,920\end{array}$ & $\begin{array}{l}3,845-4,570 \\
3,660-4,195\end{array}$ \\
\hline Aegyptopithecus zeuxis & Oligocene & $\begin{array}{l}\text { Quarry I (Fayum), Egypt } \\
\text { (Kay et al., 1981) }\end{array}$ & $\begin{array}{l}\mathrm{M}^{1}=3.74(\mathrm{n}=3) \\
\mathrm{M}_{1}=3.46(\mathrm{n}=7)\end{array}$ & $\begin{array}{l}6,495 \\
6,035\end{array}$ & $\begin{array}{l}5,935-7,110 \\
5,620-6,480\end{array}$ \\
\hline Micropithecus clarki & $\begin{array}{l}\text { Early } \\
\text { Miocene }\end{array}$ & $\begin{array}{l}\text { Napak, Uganda (Fleagle } \\
\text { and Simons, } 1978\end{array}$ & $\begin{array}{l}M^{\prime}=3.11(n=2) \\
M_{1}=3.03(n=2)\end{array}$ & $\begin{array}{l}2,340 \\
3,180\end{array}$ & $\begin{array}{l}2,120-2,585 \\
2,965-3,410\end{array}$ \\
\hline Limnopithecus legetet & $\begin{array}{l}\text { Early } \\
\text { Miocene }\end{array}$ & $\begin{array}{l}\text { Songhor, Kenya (Andrews, } \\
\text { 1978) }\end{array}$ & $\begin{array}{l}M^{1}=3.45(n=5) \\
M_{1}=3.28(n=13)\end{array}$ & $\begin{array}{l}4,060 \\
4,615\end{array}$ & $\begin{array}{l}3,725-4,425 \\
4,310-4,940\end{array}$ \\
\hline $\begin{array}{l}\text { Dendropithecus } \\
\text { macinnesi }\end{array}$ & $\begin{array}{l}\text { Early } \\
\text { Miocene }\end{array}$ & $\begin{array}{l}\text { Rusinga Is., Kenya } \\
\text { (Andrews, 1978) }\end{array}$ & $\begin{array}{l}\mathrm{M}^{1}=3.80(\mathrm{n}=13) \\
\mathrm{M}_{1}=3.64(\mathrm{n}=9)\end{array}$ & $\begin{array}{l}7,160 \\
7,890\end{array}$ & $\begin{array}{l}6,520-7,855 \\
7,305-8,525\end{array}$ \\
\hline Rangwapithecus gordoni & $\begin{array}{l}\text { Early } \\
\text { Miocene }\end{array}$ & $\begin{array}{l}\text { Songhor, Kenya } \\
\text { (Andrews, 1978) }\end{array}$ & $\begin{array}{l}M^{1}=4.19(\mathrm{n}=6) \\
M_{1}=3.95(\mathrm{n}=7)\end{array}$ & $\begin{array}{l}13,465 \\
12,525\end{array}$ & $\begin{array}{l}11,950-15,170 \\
11,415-13,740\end{array}$ \\
\hline Proconsul africanus & $\begin{array}{l}\text { Early } \\
\text { Miocene }\end{array}$ & $\begin{array}{l}\text { Rusinga Is., Kenya } \\
\text { (Andrews, 1978) }\end{array}$ & $\begin{array}{l}\mathrm{M}^{1}=4.28(\mathrm{n}=11) \\
\mathrm{M}_{1}=4.10(\mathrm{n}=4)\end{array}$ & $\begin{array}{l}15,580 \\
15,660\end{array}$ & $\begin{array}{l}13,720-17,685 \\
14,145-17,340\end{array}$ \\
\hline Proconsul nyanzae & $\begin{array}{l}\text { Early } \\
\text { Miocene }\end{array}$ & $\begin{array}{l}\text { Rusinga Is., Kenya } \\
\text { (Andrews, 1978) }\end{array}$ & $\begin{array}{l}\mathrm{M}^{1}=4.70(\mathrm{n}=7) \\
\mathrm{M}_{1}=4.37(\mathrm{n}=14)\end{array}$ & $\begin{array}{l}30,760 \\
23,420\end{array}$ & $\begin{array}{l}26,010-36,385 \\
20,770-26,410\end{array}$ \\
\hline Procansul major & $\begin{array}{l}\text { Early } \\
\text { Miocene }\end{array}$ & $\begin{array}{l}\text { Songhor, Kenya } \\
\text { (Andrews, 1978) }\end{array}$ & $\begin{array}{l}M^{1}=4.78(\mathrm{n}=5) \\
M_{1}=4.75(\mathrm{n}=7)\end{array}$ & $\begin{array}{l}35,015 \\
41,255\end{array}$ & $\begin{array}{l}29,360-41,765 \\
35,570-47,845\end{array}$ \\
\hline $\begin{array}{l}\text { European Hominoidea } \\
\text { Pliopithecus antiquus }\end{array}$ & $\begin{array}{l}\text { Late } \\
\text { Miocene }\end{array}$ & $\begin{array}{l}\text { Sansan (Gers), France } \\
\text { (Hürzeler, 1954) }\end{array}$ & $\begin{array}{l}\mathrm{M}^{t}=- \\
\mathrm{M}_{1}=3.46(\mathrm{n}=1)\end{array}$ & $\overline{6,035}$ & $5,620-6,480$ \\
\hline $\begin{array}{l}\text { Dryopithecus laietanus } \\
(?=D . \text { brancoi })\end{array}$ & $\begin{array}{l}\text { Late } \\
\text { Miocene }\end{array}$ & $\begin{array}{l}\text { La Trumba (Catalonia), } \\
\text { Spain (Simons and } \\
\text { Pilbeam, 1965) }\end{array}$ & $\begin{array}{l}\mathrm{M}^{1}=- \\
\mathrm{M}_{1}=4.14(\mathrm{n}=1)\end{array}$ & 16,624 & $\frac{-}{14,975-18,455}$ \\
\hline Dryopithecus fontani & $\begin{array}{l}\text { Late } \\
\text { Miocene }\end{array}$ & $\begin{array}{l}\text { St. Gaudens (Hte. } \\
\text { Garonnel, France } \\
\text { (Simons and Pilbeam, 1965) }\end{array}$ & $\begin{array}{l}\mathrm{M}^{1}=- \\
\mathrm{M}_{1}=4.51(\mathrm{n}=2)\end{array}$ & 28,850 & $\frac{-}{25,330-32,865}$ \\
\hline
\end{tabular}


TABLE 5. Estimated body weights of some representative species of Eocene, Oligocene, and Miocene fossil primates, based on the regression coefficients given in Table 3 . Tooth size in ln (length $\times$ width) for $M^{1}$ or $M_{1}$, with sample size $n$ as indicated. Original measurements in $\mathrm{mm}$ (continued)

\begin{tabular}{|c|c|c|c|c|c|}
\hline Genus and species & Age & $\begin{array}{c}\text { Locality } \\
\text { (reference) }\end{array}$ & $\begin{array}{c}\text { Tooth size } \\
\ln \text { (length } \times \\
\text { width) }\end{array}$ & $\begin{array}{l}\text { Estimated } \\
\text { weight } \\
\text { (gm) }\end{array}$ & $\begin{array}{l}95 \% \\
\text { Confidence } \\
\text { interval }\end{array}$ \\
\hline $\begin{array}{l}\text { Ouranopithecus } \\
\text { macedoniensis }\end{array}$ & $\begin{array}{l}\text { Late } \\
\text { Miocene }\end{array}$ & $\begin{array}{l}\text { Ravin de la Pluie (Macedonia), } \\
\text { Greece (de Bonis et al., } \\
\text { 1974, 1975, 1977) }\end{array}$ & $\begin{array}{l}\mathrm{M}^{1}=5.23(\mathrm{n}=1) \\
\mathrm{M}_{2}=5.23(\mathrm{n}=3)\end{array}$ & $\begin{array}{l}72,590 \\
84,345\end{array}$ & $\begin{array}{l}57,945-90,940 \\
70,045-101,570\end{array}$ \\
\hline $\begin{array}{r}\text { Asian Hominoidea } \\
\text { Dionysopithecus } \\
\text { shuangouensis }\end{array}$ & $\begin{array}{l}\text { Middle } \\
\text { Miocene }\end{array}$ & $\begin{array}{l}\text { Shihhung (Kiangsu), China } \\
\text { (Li, 1978) }\end{array}$ & $\begin{array}{l}\mathrm{M}^{\prime}=3.33(\mathrm{n}=1) \\
\mathrm{M}_{1}=-\end{array}$ & $\begin{array}{l}3,345 \\
-\end{array}$ & $\begin{array}{c}3,060-3,655 \\
-\end{array}$ \\
\hline $\begin{array}{l}\text { Sivapithecus } \\
\text { sivalensis }\end{array}$ & $\begin{array}{l}\text { Late } \\
\text { Miocene }\end{array}$ & $\begin{array}{l}\text { Siwaliks, India and } \\
\text { Pakistan (Simons and } \\
\text { Pilbeam, 1965) }\end{array}$ & $\begin{array}{l}\mathrm{M}^{1}=- \\
\mathrm{M}_{1}=4.60(\mathrm{n}=18)\end{array}$ & $\overline{32,990}$ & $\frac{-}{28,770-37,830}$ \\
\hline Sivapithecus indicus & $\begin{array}{l}\text { Late } \\
\text { Miocene }\end{array}$ & $\begin{array}{l}\text { Siwaliks, India and } \\
\text { Pakistan (Simons and } \\
\text { Pilbeam, 1965) }\end{array}$ & $\begin{array}{l}\mathrm{M}^{\prime}=- \\
\mathrm{M}_{1}=4.83(\mathrm{n}=8)\end{array}$ & $-\overline{46,475}$ & $39,830-54,230$ \\
\hline Sivapithecus meteai & $\begin{array}{l}\text { Late } \\
\text { Miocene }\end{array}$ & $\begin{array}{l}\text { Kazan (Anatolia), Turkey } \\
\text { (Andrews and Tekkaya, } \\
1980 \text { ) }\end{array}$ & $\begin{array}{l}M^{1}=5.09(\mathrm{n}=1) \\
M_{1}=5.04(\mathrm{n}=1)\end{array}$ & $\begin{array}{l}57,860 \\
63,550\end{array}$ & $\begin{array}{l}46,910-71,365 \\
53,575-75,380\end{array}$ \\
\hline $\begin{array}{l}\text { Gigantopithecus } \\
\text { giganteus }\end{array}$ & $\begin{array}{l}\text { Late } \\
\text { Miocene }\end{array}$ & $\begin{array}{l}\text { Haritalyangar Siwaliks, } \\
\text { India (Simons and Chopra, } \\
\text { 1969) }\end{array}$ & $\begin{array}{l}\mathrm{M}^{1}=- \\
\mathrm{M}_{1}=5.49(\mathrm{n}=1)\end{array}$ & $\begin{array}{c}- \\
124,260\end{array}$ & $\frac{-}{101,050-152,790}$ \\
\hline
\end{tabular}

However, body weights estimated from $\mathrm{M}^{1}$ and $\mathrm{M}_{1}$ in Oreopithecus bambolii are very consistent, yielding an average weight of about $15,000 \mathrm{gm}$.

Estimates of body weight in Oligocene and Miocene Hominoidea derived from upper and lower molars are, with few exceptions, reasonably consistent. In some cases discrepancies may be due to the small size of available samples. In one other case, Proconsul nyanzae from Rusinga Island, it is possible that lower teeth of a smaller species (Proconsul africanus) are included in the published sample. Estimated body weights for Miocene apes range from about $2,700 \mathrm{gm}$ in Micropithecus clarki to $124,000 \mathrm{gm}$ in Gigantopithecus giganteus.

\section{DISCUSSION}

Allometric scaling of tooth size and body size

Pilbeam and Gould (1974) and Gould (1975) reported that upper cheek teeth scale with positive allometry in a diverse range of rodents, artiodactyls, and primates lusing cranial length as a measure of body size), implying that tooth size may scale metabolically rather than geometrically. They subsequently noted that positive allometry in the upper cheek tooth row may be accomplished by a strong positive allometric increase in third molar size and in the size of the premolars, even though $\mathbf{M}^{1}$ and $\mathbf{M}^{2}$ scale geometrically (Pilbeam and Gould, 1975). Pirie (1978) duplicated Pilbeam and Gould's analysis of cheek tooth to skull length scaling for a wider range of primates and concluded that postcanine tooth area is in part related to the amount of food ingested, i.e., to metabolic rate. Similarly, Goldstein et al. (1978) found that postcanine tooth area scaled with positive allometry across a series of cercopithecoid primates representing three dietary classes.

In contrast, Kay (1975a) found that both $\mathrm{M}_{2}$ area and postcanine tooth area scaled below geometric scaling when tooth area was compared with body weight in a broad range of primates and in bovid artiodactyls. Corruccini and Henderson (1978), Wood (1979a), and Wood and Stack (1980) supported Kay's conclusion using multivariate principal axes or linear regressions of tooth size and cranial size in primates.

Gould (1975) showed that major axis (or principal axis) slopes differ systematically from least squares regression slopes in yield- 
ing a higher estimate of allometric scaling. This difference can be considerable when variates are not perfectly correlated. More recently, Smith (1981) has shown that regressions of tooth size on body size differ considerably depending on the measurement used to represent body size. Cranial length and body weight, for example, may yield very different results. In this study we have used principal axes to represent the structural relationship between tooth crown area and body weight. Our results confirm Pilbeam and Gould's (1975) inference that teeth at the front and back of the cheek tooth series scale with more positive allometry than teeth in the center of the cheek tooth series. However, stated in terms of crown area to body weight, it is clear that neither upper cheek teeth as a unit nor lower cheek teeth as a unit scale at a rate approaching metabolic scaling. Lower cheek teeth as a unit approximate geometric scaling, but the sum of crown areas of the upper cheek teeth scale significantly below even geometric scaling when the entire spectrum of generalized primates is considered.

\section{Prediction of body weight from tooth size}

There are two general problems associated with predicting the average body weight of a species from its tooth size: one concerns the accuracy of predictions based on one or more teeth, and the other concerns the consistency of predictions based on different teeth. One way to test the accuracy of body weight predictions is to compare weights predicted from tooth size with known weights in extant species. As new information about extant species used in our analysis becomes available, it will be possible to test how well weights predicted from tooth size in these new samples conform to actual body weights. A truly independent test would require predicting the body weights of additional extant species not included in the original analysis, and comparison of these predicted weights with actual weights. It is, in most cases, impossible to test the accuracy of body weights estimated for fossil primates (Table 5). The only way to test these is to compare body weights predicted from tooth size with those predicted from cranial and postcranial remains. This can be done to a limited extent for Aegyptopithecus zeuxis (Table 4), and our results based on tooth size agree reasonably well with body weights predicted from cranial size and from ulna size.

Since all available information on tooth size and body size in extant primates was used in our analysis, we can at present only model the dispersion of body size predictions based on tooth size for each of the major groups of generalized primates (Fig. 6). The average weight predicted for each species from $M_{1}$ or $\mathrm{M}^{1}$ size is plotted on the ordinate for comparison with the known average weight on the abscissa. Ideally, if predicted weights were equal to actual weights, all species would fall on the dashed diagonal line. Species in each of the four systematic groups shown in Figure 6 all show about the same amount of dispersion about the diagonal.

As a measure of consistency, body weight predictions based on $\mathrm{M}^{2}$ (open circles) can be compared with those based on $\mathrm{M}_{1}$ (solid circles) in Figure 6. In many cases these are equal (halfclosed circles), but in others there is a substantial difference between body weights predicted from $\mathrm{M}^{1}$ and those predicted from $\mathrm{M}_{1}$. Upper teeth give substantially greater predicted body weights than those based on lower teeth in five out of the six species of Lemuroidea and Lorisoidea shown. Predicted weights based on upper molars are equal to or, in most cases, greater than actual weights, indicating that upper molars of prosimian Lemuroidea and Lorisoidea usually overestimate body weight. On the other hand, predicted weights based on $\mathrm{M}_{1}$ are about equally dispersed above and below the diagonal, indicating that $M_{1}$ provides a more accurate body weight prediction than $M_{1}$ does. This result suggests that the body weights of Adapidae in Table 5 based on lower molars are probably more reliable than those based on upper molars.

Prosimians have distinctly larger (broader) upper molars than higher primates do, and this distinction is reflected in our observation that upper molars of prosimians alone tend to overestimate body weight. Higher primates as a group have narrower upper molars than prosimians do, and since these contributed the majority of species used to construct our prediction equations, predictions should be more accurate for these primates. Apart from prob. lems caused by the relatively broader upper molars of prosimians, it appears that body weight predictions based on upper and lower molars in generalized primates are reasonably consistent.

Our estimates of the body weights of Fayum primates differ from those of Kay and Simons (1980) by factors ranging from 1.07 in the case of Aegyptopithecus to 1.91 in Oligopithecus. These differences may be explained in part by 

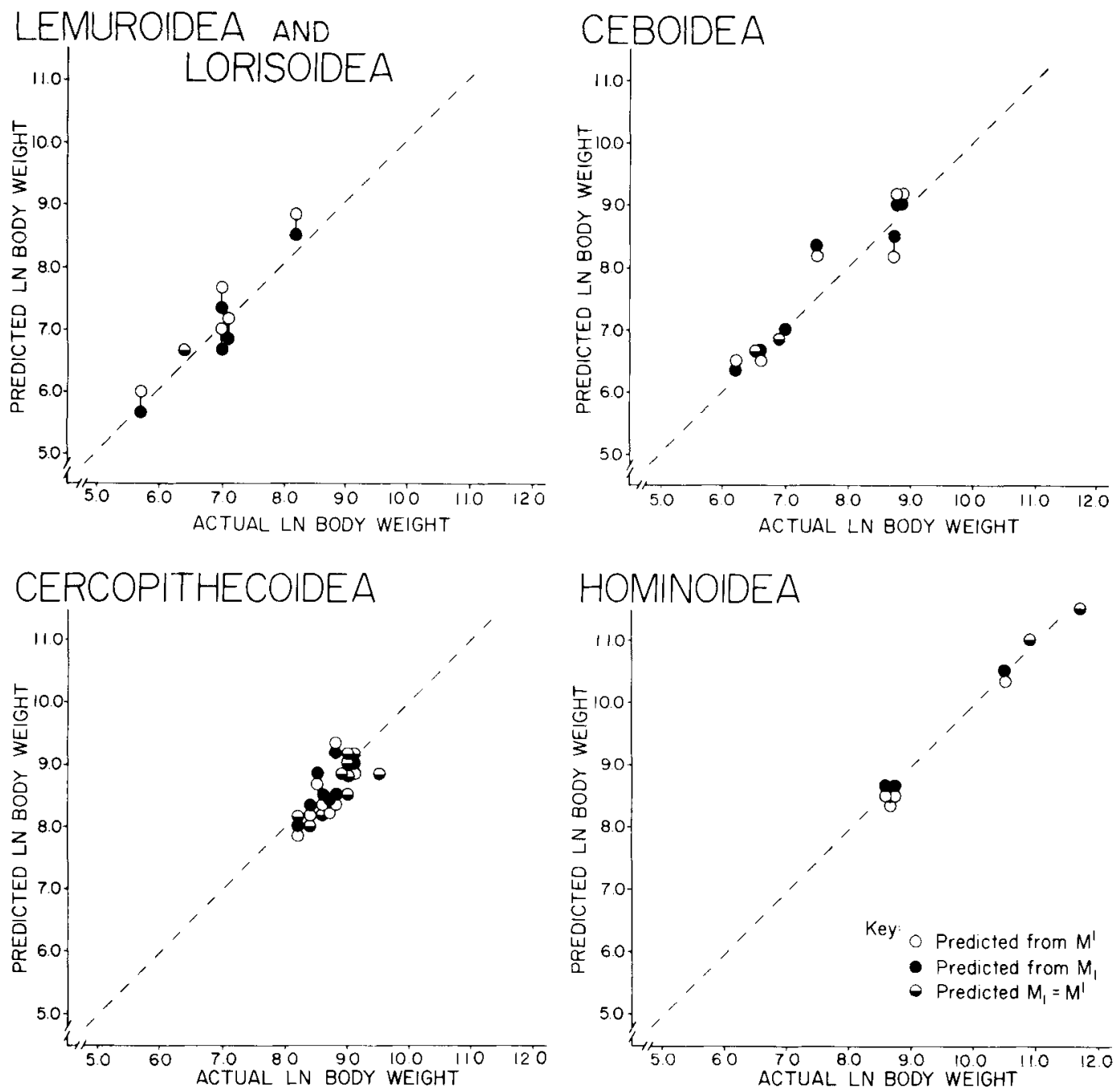

Fig. 6. Comparison of body weights predicted from tooth size (ordinate) with actual body weights (abscissa) for living Lemuroidea and Lorisoidea, Ceboidea, Cercopithecoidea, and Hominoidea based on data and equations in Tables 1 and 3. Dashed diagonal line represents a predicted body weight equal to the actual weight. Each circle is the average weight of a species predicted from $\mathbf{M}^{1}$ (open circles) or $\mathbf{M}_{1}$ (solid circles). Half shaded circles indicate species for which body size predictions based on $M^{1}$ and $M_{1}$ coincide. Note that $M^{1}$ yields body weight estimates substantially greater than those based on $M_{1}$ for Lemuroidea and Lorisoidea, and that estimates based on $M_{1}$ tend to approximate actual weights (dashed line) more closely than do estimates based on $\mathbf{M}^{1}$. Upper and lower molars both appear to yield reasonably accurate predicted body weights for Ceboidea, Cercopithecoidea, and Hominoidea.

the use of $M_{1}$ rather than $M_{2}$ measurements and in part by the fact that we included measurements of both length and width in calculating our estimates. Kay and Simons' estimates are based on the length of $M_{2}$ in each of the species studied. Among Miocene primates, our estimate of the average body weight of
Proconsul africanus based on the crown area of $M_{1}(15,620 \mathrm{gm})$ differs from that based on $M_{2}$ length $(23,400 \mathrm{gm}$; Gingerich, 1977a) by a factor of 1.50. Andrews' (1978) measurements of $\mathrm{M}_{2}$ in Rusings $P$. africanus and critical values from Table 3 yield a predicted body weight of $15,240 \mathrm{gm}(95 \%$ confidence interval $=$ 
$13,825-16,740 \mathrm{gm})$, which agrees with our estimate based on $M_{1}$. Since our new estimates are based on tooth length and width, not just length, we feel $15,000-16,000 \mathrm{gm}$ is a better estimate for the body weight of Proconsul africanus than the 23,000-24,000 gm estimate given previously.

\section{CONCLUSIONS}

Much remains to be learned about allometric scaling of tooth size and body weight in the dentition of primates and other mammals. Our results demonstrate that there is a coherent pattern of differences in scaling at different tooth positions across the whole range of generalized primates. We have not investigated how this general pattern might change if primates were subdivided into smaller taxonomic groups or into dietary guilds. Some taxonomic groups of living primates (Lemuroidea, Ceboidea, Cercopithecoidea) are large enough to justify separate allometric treatment and separate body size prediction equations when adequate measurements of tooth size and body weight become available. Continued investigation of the relationship of tooth size and body size promises to clarify the functional relationship of these characteristics. This in turn should permit a much more perceptive understanding of dental, dietary, and body size adaptations in fossil primates.

\section{ACKNOWLEDGMENTS}

A preliminary version of this paper was presented at the 1980 annual meeting of the American Association of Physical Anthropologists (Gingerich et al., 1980). We are particularly indebted to Dr. E.D. Rothman, Department of Statistics, The University of Michigan, for advice in constructing confidence intervals. We thank J.G. Fleagle, S.M. Garn, R.F. Kay, D.W. Krause, D.E. Moerman, D.R. Pilbeam, and R.J. Smith for comments on the manuscript. We also thank Karen Payne for drawing the figures. This research was supported by a grant from the National Science Foundation (BNS 80-16742).

\section{LITERATURE CITED}

Alexander, RM, Jayes, AS, Maloiy, GM, and Wathuta, EM (1979) Allometry of the limb bones of mammals from shrews (Sorex) to elephant (Loxodonta). J. Zool., Lond. 189:305-314.

Andrews, PJ (1978) A revision of the Miocene Hominoidea of East Africa. Bull. Br. Mus. Nat. Hist., Geol. 30:85-224.

Andrews, $P$, and Tekkaya, I (1980) A revision of the Turkish Miocene hominoid Sivapithecus meteai. Palaeontology 23:85-95.

Bauchot, R, and Stephan, H (1966) Données nouvelles sur l'encéphalisation des insectivores et des prosimiens. Mammalia 30:160-196.

Bauchot, R, and Stephan, H (1969) Encéphalisation et niveau évolutif chez les simiens. Mammalia 33:4-275.

Bonis, L de, Bouvrain, G, Geraads, D, and Melentis, J (1974) Première découverte d'un primate hominoide dans le Miocène supérieur de Macédoine (Grèce). C.R. Acad. Sci. Paris 278:3063-3066.

Bonis, L de, Bouvrain, G, and Melentis, J $\{1975\}$ Nouveaux restes de Primates hominoides dans le Vallesian de Macédoine (Grèce). C.R. Acad. Sci. Paris 281:379-382.

Bonis, L de, and Melentis, J (1977) Un nouveau genre de Primate hominoide dans le Vallésien (Miocène supérieur) de Macédoine. C.R. Acad. Sci. Paris 284:1393-1396.

Clutton-Brock, TH, and Harvey, PH (1977) Species differences in feeding and ranging behaviour of primates. In: TH Clutton-Brock (ed): Primate Ecology: Studies of Feeding and Ranging Behaviour in Lemurs, Monkeys, and Apes. London: Academic Press, pp. 557-584.

Clutton-Brock, TH, Harvey, PH, and Rudder, B (1977) Sexual dimorphism, socionomic sex ratio and body weight in primates. Nature 269:797-800.

Corruccini, RS, and Henderson, AM (1978) Multivariate dental allometry in primates. Am. J. Phys. Anthropol. 48:203-208.

Creighton, GK (1980) Static allometry of mammalian teeth and the correlation of tooth size and body size in contemporary mammals. J. Zool., Lond. 191:435-443.

Draper, NR, and Smith, H (1966) Applied Regression Analysis. New York: John Wiley and Sons, Inc.

Fleagle, JG (1978) Size distributions of living and fossil primate faunas. Paleobiology 4:67-76.

Fleagle, JG, and Mittermeier, RA (1980) Locomotor behavior, body size, and comparative ecology of seven Surinam monkeys. Am. J. Phys. Anthropol. 52:301 -314.

Fleagle, JG, and Simons, EL (1978) Micropithecus clarki, a small ape from the Miocene of Uganda. Am. J. Phys. Anthropol, 49:427-440.

Fleagle, JG, Simons, EL, and Conroy, GC (1975) Ape limb bone from the Oligocene of Egypt. Science 189:135-137.

Garn, SM, and Lewis, AB (1958) Tooth-size, body-size and "giant" fossil man. Am. Anthropol. 60:874-880.

Gingerich, PD (1976) Cranial Anatomy and Evolution of Early Tertiary Plesiadapidae (Mammalia, Primates). Univ. Mich. Pap. Paleontol. 15:1-141.

Gingerich, PD (1977a) Correlation of tooth size and body size in living hominoid primates, with a note on relative brain size in Aegyptopithecus and Proconsul. Am. J. Phys. Anthropol. 47:395-398.

Gingerich, PD (1977b) New species of Eocene primates and the phylogeny of European Adapidae. Folia Primatol. 28:60-80.

Gingerich, PD (1977c) Radiation of Eocene Adapidae in Europe. Géobios, Mém. Spécial 1:165-182.

Gingerich, PD (1978) The Stuttgart collection of Oligocene primates from the Fayum province of Egypt. Paläont. Z. 52:82-92.

Gingerich, PD (1979) Phylogeny of middle Eocene Adapidae (Mammalia, Primates) in North America: Smilodectes and Notharctus. J. Paleontol. 53:153-163.

Gingerich, PD (1981) Early Cenozoic Omomyidae and the evolutionary history of tarsiiform primates. J. Hum. Evol. 10:345-374.

Gingerich, PD, and Ryan, AS (1979) Dental and cranial variation in living Indriidae. Primates 20:141-159.

Gingerich, PD, and Simons, EL (1977) Systematics, phylogeny, and evolution of early Eocene Adapidae (Mammalia, Primates) in North America. Contrib. Mus. Paleontol., Univ. Mich. 24:245-279.

Gingerich, PD, Smith, BH, and Rosenberg, K (1980) Patterns of allometric scaling in the primate dentition and 
prediction of body size from tooth size. Am. J. Phys. Anthropol. 52:231-232 (Abstract).

Goldstein, S, Post, D, and Melnick, D (1978) An analysis of cercopithecoid odontometrics: I. The scaling of the maxillary dentition. Am J. Phys. Anthropol. 49:517-532.

Gould, SJ (1966) Allometry and size in ontogeny and phylogeny. Biol. Rev. 41:587-640.

Gould, SJ (1975) On the scaling of tooth size in mammals. Amer. Zool. 15:351-362.

Harvey, PH, Kavanagh, M, and Clutton-Brock, TH (1978) Sexual dimorphism in primate teeth. J. Zool., Lond. 186:475-485.

Hershkovitz, P (1970) Notes on Tertiary platyrrhine monkeys and description of a new genus from the late Miocene of Colombia. Folia Primatol. 12:1-37.

Hoffstetter, MR (1969) Un primate de l'Oligocène inférieur Sud-Américain: Branisella boliviana gen. et sp. nov. C.R. Acad. Sci. Paris 269:434-437.

Hürzeler, J (1954) Contribution à l'odontologie et à la phylogénese du genre Pliopithecus Gervais. Ann. Paléontol. 40:1-63.

Hürzeler, J (1958) Oreopithecus bambolii Gervais. Verh. Naturf. Ges. Basel 69:1-48.

Hutchinson, GE, and MacArthur, RH (1959) A theoretical ecological model of size distributions among species of animals. Am. Nat. 93:117-125.

Huxley, JS (1932) Problems of Relative Growth. London: Methuen.

Hylander, WS (1975) Incisor size and diet in anthropoids with special reference to Cercopithecidae. Science 189:1095-1098.

Jolicoeur, P (1973) Imaginary confidence limits of the slope of the major axis of a bivariate normal distribution: A sampling experiment. J. Am. Stat. Assoc. 68:866-871.

Kay, RF (1975a) Allometry and early hominids. Science 189:61-64.

Kay, RF (1975b) The functional adaptations of primate molar teeth. Am. J. Phys. Anthropol. 43:195-216.

Kay, RF (1978) Molar structure and diet in extant Cercopithecidae. In: PM Butler and KA Joysey (eds): Development, Function and Evolution of Teeth. London: Academic Press, pp. 309-339.

Kay, RF, and Hylander, WL (1978) The dental structure of mammalian folivores with special reference to Primates and Phalangeroidea (Marsupalia). In: GG Montgomery (ed): The Biology of Arboreal Folivores. Washington: Smithsonian Institution Press, pp. 173-191.

Kay, RF, and Simons, EL (1980) The ecology of Oligocene African Anthropoidea. Int. J. Primatol. 1:21-37.

Kay, RF, Simons, EL, and Fleagle, JG (1981) A revision of the Oligocene apes of the Fayum province, Egypt. Am. J. Phys. Anthropol., 55:293-322.

Koenigswald, GHR von (1969) Miocene Cercopithecoidea and Oreopithecoidea from the Miocene of East Africa. In: LSB Leakey (ed): Fossil Vertebrates of Africa, v. I. London: Academic Press, pp. 39-51.

Lande, $R$ (1977) On comparing coefficients of variation. Syst. Zool. 26:214-217.

Leutenegger, W (1976) Allometry of neonatal size in eutherian mammals. Nature 263:229-230.

$\mathrm{Li}, \mathrm{CK}$ (1978) A Miocene gibbon-like primate from Shihhung, Kiangsu Province. Vertebrata Palasiatica 16:187-192.
McMahon, T (1973) Size and shape in biology. Science 179:1201-1204.

McNab, BK (1971) On the ecological significance of Bergmann's rule. Ecology 52:845-854.

Milton, K, and May, ML (1976) Body weight, diet and home range area in primates. Nature 259:459-462.

Pilbeam, D, and Gould, SJ (1974) Size and scaling in human evolution. Science 186:892-901.

Pilbeam, D, and Gould, SJ (1975) Allometry and early hominids. Science 189:61-64.

Pirie, PL (1978) Allometric scaling in the postcanine dentition with reference to primate diets. Primates 19:583-591.

Sacher, GA (1959) Relation of lifespan to brain weight and body weight in mammals. In: GEW Wolstenholme and $M$ O'Connor (eds): CIBA Foundation Symposium on the Lifespan of Animals. London: Churchill, pp. 115-133.

Schmidt-Nielsen, K (1975) Scaling in biology: The consequences of size. J. Exp. Zool. 194:287-307.

Simons, EL (1962) Two new primate species from the African Oligocene. Postilla 64:1-12.

Simons, EL (1969) Miocene monkey (Prohylobates) from northern Egypt. Nature 223:687-689.

Simons, EL (1974) Parapithecus grangeri (Parapithecidae, Old World Higher Primates) new species from the Oligocene of Egypt and the initial differentiation of Cercopithecoidea. Postilla 166:1-12.

Simons, EL, and Chopra, SRK (1969) Gigantopithecus (Pongidae, Hominoidea) a new species from North India. Postilla 138:1-18.

Simons, EL, and Pilbeam, DR (1965) Preliminary revision of the Dryopithecinae (Pongidae, Anthropoidea). Folia Primatol. 3:81-152.

Smith, RJ (1980) Rethinking allometry. J. Theor. Biol. 87:97-111.

Smith, RJ (1981) On the definition of variables in studies of primate dental allometry. Am. J. Phys. Anthropol. 55:323-329.

Sokal, RR, and Rohlf, FJ (1969) Biometry. San Francisco: WH Freeman and Company.

Stirton, RA (1951) Ceboid monkeys from the Miocene of Colombia. Bull. Dept. Geol. Sci., Univ. Calif. 28:315-356.

Swindler, DR (1976) Dentition of Living Primates. London: Academic Press.

Van Valen, L (1973) Body size and numbers of plants and animals. Evolution 27:27-35.

Western, D (1979) Size, life history and ecology in mammals. Afr. J. Ecol. 17:185-204.

Wilson, JA, and Szalay, FS (1976) New adapid primate of European affinities from Texas. Folia Primatol. 25:294-312.

Wood, BA (1979a) An analysis of tooth and body size relationships in five primate taxa. Folia Primatol. 31:187-211.

Wood, BA (1979b) Models for assessing relative canine size in fossil hominids. J. Hum. Evol. 8:493-502.

Wood, BA, and Stack, CG (1980) Does allometry explain the differences between "gracile" and "robust" australopithecines? Am. J. Phys. Anthropol. 52:55-62.

Yablokov, AV (1974) Variability of Mammals. New Delhi: Amerind Publishing Co. Pvt. Ltd. 